\title{
A Strategic Activity Model of Enterprise System Implementation and Use: Scaffolding Fluidity
}

\begin{abstract}
This paper builds on a Strategic Activity Framework (Jarzabkowski 2005) and activity based theories of development (Vygotsky 1978) to model how Enterprise Systems are used to support emerging strategy. It makes three contributions. Firstly, it links fluidity and extensiveness of system use to patterns of strategising. Fluidity - the ability to change system use as needs change - is supported by interactive strategising, where top managers communicate directly with the organisation. Extensiveness requires procedural strategising, embedding system use in structures and routines. Secondly, it relates interactive and procedural strategising to the importance of the system procedural strategising is more likely to occur if the system is strategically important. Thirdly, using a scaffolding metaphor it identifies patterns in the activities of top managers and Enterprise System custodians, who identify process champions within the organisational community, orient them towards system goals, provide guided support, and encourage fluidity through pacing implementation with learning.
\end{abstract}

\section{Keywords}

Enterprise Systems, Strategy as Practice, Scaffolding 


\section{Introduction}

This paper uses a Strategy as Practice lens (Whittington 1996, Jarzabkwoski 2005) supplemented by activity based theories of development (Vygotsky 1978, 1930) to examine how leadership teams and Enterprise System custodians guide an organisational community into using its Enterprise Systems to support strategic goals. The strategic role that Enterprise Systems play in organisations is complex. Such systems, which integrate key business processes within and between organisations, offer opportunities for better integrated data, optimised processes, and better access to management information (Seddon et al 2010). Organisations differ, however, in their ability to make use of such systems, for several reasons.

Firstly, the potential benefits of Enterprise Systems are not always directly related to an organisation's strategy. Organisations may have business models based on highly tailored, flexible processes that would not benefit from standardisation, for example (Davenport 1998, Davenport et al 2004). They may also have multiple strategies (Jarzabkowski 2005), each impacted differently, if at all, by Enterprise Systems. The differences in strategic benefits that organisations can obtain from such systems is reflected in a wide variety of business cases for them (Markus and Tanis 2000, Robey et al 2002). This complexity in the relationship between potential benefits and organisational strategies leads to the first research question:-

How are Enterprise System practices related to the multiple strategies of the organisation?

Secondly, strategies are dynamic and emergent (Mintzberg and Waters 1985, Brown and Eisenhardt 1998) and Enterprise Systems must therefore support changing needs (Lee and Myers 2004). This does not always happen: implementation and use of Enterprise Systems consists of several phases, and activities in earlier phases can limit further opportunities. (Markus and Tanis 2000, Dechow and Mouritsen 2005). Systems can be: "like cement... highly flexible in the beginning, but rigid later" (Davenport 2000 p 16). Preventing this rigidity requires an involved, knowledgeable organisational community: one that learns. (Robey et al 2002, Srivardhana and Pawlowski 2007).

Such learning requires motivation and time. The activities of the top management team in continuing to motivate the organisational community are important in this regard (Davenport 1998). So, too, are the activities of the custodians of the Enterprise System - the team responsible for its use within the broader community (Volkoff et al 2004, Srivardhana and Pawlowski 2007). The second research question explored in this paper, therefore, is:-

How do the activities of the Top Management Team and Enterprise System custodians guide the organisational community with regard to evolving Enterprise System practices?

This paper extends previous research in three ways. Its first contribution is to link patterns of strategising by top managers during each phase of an implementation with the fluidity and extensiveness of system use. Fluidity requires motivating individuals to learn to use the system knowledgeably - to understand its process and data implications. High levels of interactions between top managers and members of the organisational community can motivate such learning. Extensive system use is encouraged by procedural activity by top managers, embedding system use in roles, routines and structures. Integrating interactive and procedural strategising - integrative strategising - can help ensure both fluidity and extensive use. 
The second contribution is to explore the relationship between an organisation's strategies and its Enterprise Systems. There is broad variation in this relationship - some strategies are directly impacted by the systems, others tangentially, or not at all. Top managers are more likely to use integrative strategising where the system is seen as critical to strategic need.

The third contribution is to identify the practices of top managers and Enterprise System custodians in supporting organisational learning. These can be described using a modified scaffolding metaphor (Wood et al 1976, Wood 1988, Stone 1998) based in activity theory (Vygotsky 1978, 1930). Four main scaffolding practices are identified: recruitment within the organisational community, goal orientation, provision of guided support, and encouragement of fluidity. Mechanisms used as part of these scaffolding practices include the provision of governance structures and processes, identification of and support for Enterprise System 'champions', culture change initiatives, establishing principles of engagement, demonstrating the benefits of using the system, linking the system to broader organisational goals, and prioritisation and pacing to facilitate informed system use.

This paper contributes to improved practice in Enterprise Systems use. Investment in Enterprise Systems is very large, of the order of tens of billions of (US) dollars worldwide (Seddon et al 2010). There has been a large number of failed, compromised and incomplete Enterprise System implementations across a wide range of industries (Scott and Vessey 2000, Davenport et al 2004), including the University sector which forms the basis of the research in this paper (Sillince and Mouakket 1998, Baumber and Mullarvey 2000, Auditor's Report 2003).

\section{Literature Review}

The literature review is in three sections. Previous literature on Enterprise Systems and strategy is discussed, and the need for a practice approach endorsed. This is followed by a review of the Strategy as Practice literature, and a review of activity based theories of development.

\section{Enterprise Systems and their strategic role}

Enterprise Systems are integrated solutions that support key business processes within and between organisations (Seddon et al 2010). Such systems include Finance, Human Resources, Supply Chain, Sales and Marketing, Management Reporting and Metrics, Planning and Analysis, Performance Management, Product Development, and Customer Relationship Management (Davenport et al 2004). They also support the core activities of specialist sectors, such as medical records and patient administration in the health care sector, and student records and administration in education.

Variance, process and actor models have been developed which shed light on the relationship between Enterprise Systems and their strategic role. Variance models identify the outcomes from Enterprise Systems implementations, and link these to antecedent conditions. Process models seek to explain emergent change. Models based on agency specifically explore human and technical agents, and the way they interact. Table 1 summarises these models which are now discussed further. 
Table 1: Approaches to studying Enterprise Systems and their strategic role

\begin{tabular}{|c|c|c|c|}
\hline Approach & Studies & Contributions & Gaps \\
\hline \multicolumn{4}{|c|}{ Variance models } \\
\hline $\begin{array}{l}\text { Effect on } \\
\text { benefits }\end{array}$ & $\begin{array}{l}\text { Davenport } \\
1998, \\
\text { Davenport, } \\
\text { Harris et al } \\
2004, \\
\text { Seddon et al } \\
2010\end{array}$ & $\begin{array}{l}\text { Outcome explored: business } \\
\text { benefits/value. } \\
\text { Predictor variables: functional } \\
\text { fit and overcoming } \\
\text { organisational inertia; activities } \\
\text { to "integrate, optimise and } \\
\text { informate"; business } \\
\text { involvement, ongoing project- } \\
\text { based process change }\end{array}$ & 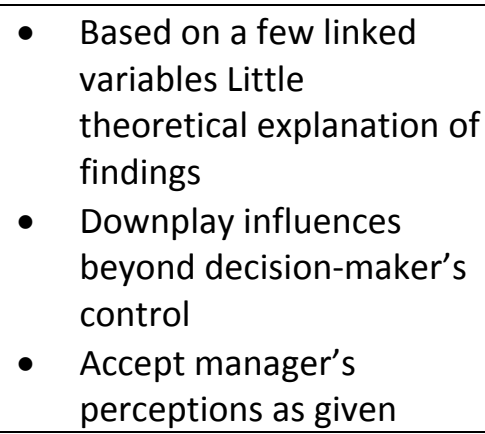 \\
\hline $\begin{array}{l}\text { Effect on } \\
\text { process } \\
\text { change }\end{array}$ & $\begin{array}{l}\text { Srivardhana and } \\
\text { Pawlowski } 2007\end{array}$ & $\begin{array}{l}\text { Outcome: ES enabling and } \\
\text { constraining process change } \\
\text { - Factors affecting process } \\
\text { change: knowledge and } \\
\text { organisational learning }\end{array}$ & $\begin{array}{l}\text { Does not explain how } \\
\text { organisational learning } \\
\text { occurs, nor how it } \\
\text { enables process change }\end{array}$ \\
\hline \multicolumn{4}{|c|}{ Process models } \\
\hline $\begin{array}{l}\text { Stages of } \\
\text { growth }\end{array}$ & $\begin{array}{l}\text { Markus and } \\
\text { Tanis 2000, } \\
\text { Ross and Vitale } \\
2000\end{array}$ & $\begin{array}{l}\text { - Wide variety of goals for ES } \\
\text { implementation } \\
\text { - } \quad \text { ES implementation phased } \\
\text { - Chance and randomness occur } \\
\text { during phases } \\
\text { - Path dependency between } \\
\text { phases }\end{array}$ & $\begin{array}{l}\text { - Imply an order, based on } \\
\text { a "stages of growth" } \\
\text { concept, which may not } \\
\text { be true in practice } \\
\text { - Does not account for a } \\
\text { wide variety of goals } \\
\text { - Does not model the way } \\
\text { in which actors interact }\end{array}$ \\
\hline $\begin{array}{l}\text { Organis- } \\
\text { ational } \\
\text { learning }\end{array}$ & $\begin{array}{l}\text { Robey et al } \\
2002, \\
\text { Volkoff et al } \\
2004 \\
\text { Wagner and } \\
\text { Newell } 2007 \\
\text { Tomblin } 2010\end{array}$ & $\begin{array}{l}\text { - Acknowledges ES potential for } \\
\text { integration } \\
\text { - Indicates how practices can } \\
\text { benefit an organisation } \\
\text { - Discusses situated learning and } \\
\text { timing of participation } \\
\text { - Discusses knowledge transfer }\end{array}$ & $\begin{array}{l}\text { - Applies learning concept } \\
\text { to organisation as a } \\
\text { whole } \\
\text { - Does not account for } \\
\text { wide variety of goals } \\
\text { - Does not model the way } \\
\text { in which actors interact }\end{array}$ \\
\hline \multicolumn{4}{|c|}{ Agency models } \\
\hline $\begin{array}{l}\text { Critical } \\
\text { ethno- } \\
\text { graphy }\end{array}$ & $\begin{array}{l}\text { Lee and Myers } \\
2004\end{array}$ & $\begin{array}{l}\text { - Changes in strategy affecting } \\
\text { Enterprise integration }\end{array}$ & $\begin{array}{l}\text { Does not model learning } \\
\text { processes between actors }\end{array}$ \\
\hline $\begin{array}{l}\text { ANT and } \\
\text { boundary } \\
\text { objects }\end{array}$ & $\begin{array}{l}\text { Dechow and } \\
\text { Mouritsen } 2005\end{array}$ & $\begin{array}{ll}\text { - } & \text { Acknowledges perceived ES } \\
\text { potential for integration } \\
\text { - } \\
\text { Models successful } \\
\text { implementations } \\
\text { - } \\
\end{array}$ & $\begin{array}{l}\text { - Does not address the } \\
\text { issue of multiple goals } \\
\text { - } \quad \text { Does not model learning } \\
\text { processes between actors }\end{array}$ \\
\hline $\begin{array}{l}\text { Foucault's } \\
\text { dressage }\end{array}$ & $\begin{array}{l}\text { Berente et al } \\
2010\end{array}$ & $\begin{array}{l}\text { - Acknowledges ES potential for } \\
\text { control via integration } \\
\text { - Investigates a situation where } \\
\text { this control has not occurred. } \\
\text { - Identifies demonstrative } \\
\text { control: the appearance of } \\
\text { control rather than the reality }\end{array}$ & $\begin{array}{l}\text { - Does not address the } \\
\text { issue of multiple goals } \\
\text { - Does not model learning } \\
\text { processes between actors }\end{array}$ \\
\hline
\end{tabular}




\section{Variance models}

Variance models have identified three potential strategic benefits from Enterprise Systems: improved integration of data; optimisation and standardisation of processes; and accessibility to management information. In the long term, these potential benefits are only achieved where there is significant organisational activity motivated by top managers (Davenport 1998, Seddon et al 2010). In the short term, benefits also depend on the functional fit of the system and the organisation's ability to change (Seddon et al 2010). A recent variance model has identified another potential benefit of Enterprise Systems: their ability to support sustained business process change. This ability is contingent on organisational learning. (Srivardhana and Pawlowski 2007).

\section{Process models}

Process models seek to explain emergent change during the lifecycle of an Enterprise Systems implementation and subsequent use ( Markus and Tanis 2000, Ross and Vitale 2000, Robey et al 2002, Volkoff et al 2004, Tomblin 2010). They stress the breadth of implementation goals, which may include fixing maintenance problems with legacy systems, reducing operating costs (Markus and Tanis 2000, Ross and Vitale 2000, Robey et al 2002), presenting 'one face to the customer', understanding inventory levels (Markus and Tanis 2000), improving business processes, data visibility (Ross and Vitale 2000, Robey et al 2002), and regulatory compliance (Robey et al 2002).

Some process models take a phased approach. Four phases have been identified: preimplementation, the implementation itself, an immediate go live phase, and an ongoing phase (Markus and Tanis 2000, Ross and Vitale 2000). A further phase, transformation, has also been identified, although not found in practice (Ross and Vitale 2000). Phased models identify path dependencies, as unresolved risks from early phases, including resistance to change, limit the success of later phases (Markus and Tanis 2000).

Some process models recognise and explore the role of organisational learning and knowledge. Enterprise Systems require a general understanding of business processes that may extend beyond an individual's immediate responsibilities into cross-functional activity (Ross and Vitale 2000, Tomblin 2010). Assimilation of new work processes requires training, and the pacing of the implementation to allow people to learn new processes. It also requires decisions regarding whether to separate process change from implementation (Robey et al 2002). A key mechanism for organisational learning is the transfer of knowledge from Enterprise System custodians to the organisational community. "Power users" are sometimes identified from specific user areas who work with Enterprise Systems custodians to train the broader user group in their area (Volkoff et al 2004). One model stresses the importance of iterative, situated learning post implementation. (Wagner and Newell 2007).

\section{Models that include agency}

The claim that Enterprise Systems provide benefits from integration has been questioned in models that consider the agency of both human and non-human actors. These benefits may be illusory. An Enterprise System implementation may draw attention to the importance of integration, and of control, but not provide it in practice (Berente et al 2010, Dechow and Mouritsen 2005). It may also introduce path dependencies, where opportunities arising from system use at one time can lead to actions which then limit further opportunities (Dechow and Mouritsen 2005). Enterprise Systems 
may have the potential to provide strategic benefits from integration, but that can be impacted by politically driven changes to strategy (Lee and Myers 2004).

\section{Summary of Enterprise Systems and their strategic role}

Regardless of the models applied, studies of Enterprise Systems indicate that they may bring benefits from integration, process optimisation and access to management information. These benefits are only achieved by ongoing organisational activity, supported by top managers (Davenport 1998, Davenport et al 2004, Seddon et al 2010), and even then may be perceived rather than actual (Dechow and Mouritsen 2005, Berente et al 2010). The relationship of such benefits to strategy is complex, as indicated by the multiplicity of goals of Enterprise Systems implementations (Markus and Tanis 2000, Ross and Vitale 2000, Robey et al 2002), and by the dynamic nature of both strategy and Enterprise Systems support (Lee and Myers 2004).

The implementation of an Enterprise System is a long process that can be described by phasing (Markus and Tanis 2000, Ross and Vitale 2000) and followed by ongoing change (Davenport et al 2004, Seddon et al 2010). Path dependencies can be introduced in early phases of an implementation that limit options in later phases: system use may become rigid and unable to respond to changing need (Davenport et al 2004, Dechow and Mouritsen 2005, Markus and Tanis 2000). Preventing such rigidity requires organisational learning, supported by Enterprise System custodians. This needs to be paced with system rollout. (Robey et al 2002, Srivardhana and Pawklowski 2007).

This literature shows that there has been considerable development in our understanding of Enterprise System benefits, the long timeframes and breadth of goals involved in system implementation, and the need to avoid system rigidity by organisational learning. There are, however, still areas that warrant research attention, and on which a practice view could shed light.

The importance of the activities of top managers in motivating organisational activity (Davenport 1998) and of Enterprise System custodians in supporting organisational learning (Volkoff et al 2004, Srivardhana and Pawklowski 2007) has been identified. The nature of these activities is not well understood, and is therefore explored using a Strategy as Practice perspective, described in the next section.

Phasing in Enterprise System implementations is currently modelled as a general concept. It assumes that every organisation undertakes the same phases in the same order. This may not always be correct - for example, organisational change may precede implementation in one organisation and succeed it in another (Robey 2002). Moreover, such phasing underplays the importance of context. In common with maturity models arising from a 'stages of growth' approach (Piaget 1926, Gibson and Nolan 1974, Galliers and Sutherland 1991, Luftman 2000), there is an implicit understanding that organisations will proceed in the same way. An activity-based view offers a different conceptual underpinning arising from a contextualised, social view of development (Vygotsky 1978, 1930). It also offers a metaphor for learning (Wood et al 1976, Stone 1998). The last section of this review therefore gives an account of activity-based theories of development. 


\section{Strategy as Practice}

The concept of Strategy As Practice gained greater prominence in 1996, focussing on "strategy as a social practice, on how practitioners of strategy really act and interact" (Whittington $1996 \mathrm{p} \mathrm{731).}$ Drawing on practice theory, Whittington distinguished the Strategy As Practice approach from three other approaches to strategy. The planning perspective, as espoused by Porter $(1980,1985)$ focuses on strategic tools and techniques available to managers. The policy perspective - see for example Markides (1995) - focuses on the organisation as a whole, and the costs and benefits of pursuing different strategic directions. The process perspective (Pettigrew 1985, Galliers 2007, 2011) is again focussed on the organisation as a whole, and provides insight into how organisations recognise the need for, and implement strategic change. The strategy as practice perspective is most closely aligned with the process school, but focuses on the practices of managers - how they strategise.

Since 1996, several developments have occurred in the strategy as practice field. A strategy as practice handbook has been produced (Golsorkhi et al 2010). This handbook examines ontological and epistemological questions, theoretical directions and methodologies. It explores links to structuration theory (Orlikowski 2010, Whittington 2010) and activity theory (Gomez 2010, Jarzabkowski 2010). An activity theory framework for Strategy as Practice (Jarzabkowski 2005) has also been developed. This paper uses a modified form of the activity framework, which Figure 1 illustrates.

Figure 1: An activity theory framework for strategy as practice (Jarzabkowski 2005 figure $2.1 \mathrm{p} 43$ )

Subject:

Top managers

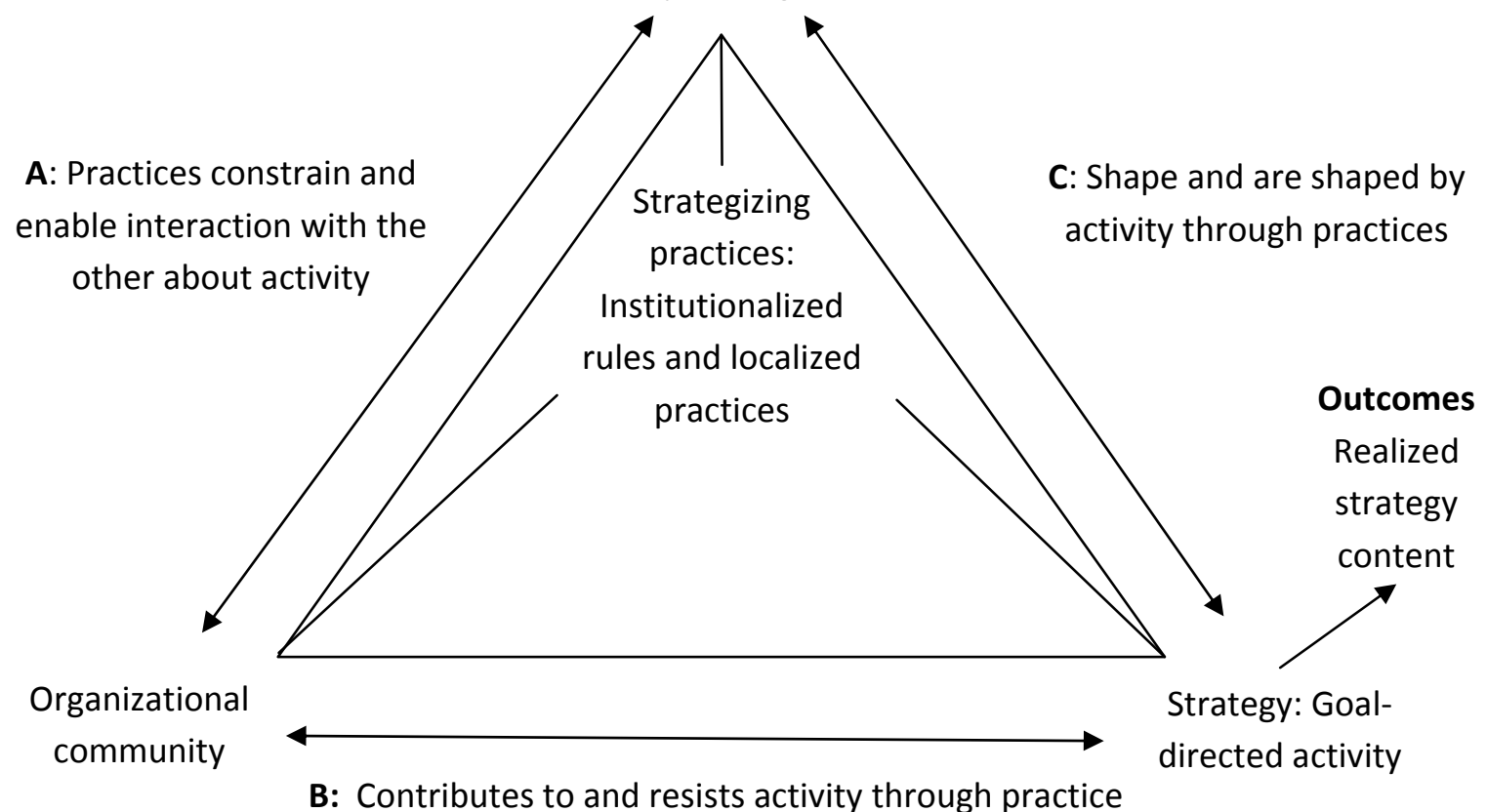

B: Contributes to and resists activity through practice

In Jarzabkowski's (2005) framework, the top management team interacts with the organisational community, attempting to shape the way members of the community contribute to strategy within the organisation. Strategising practices "act as mediators that constrain and enable the interactions between the top managers and their organisational community (arrow A)...mediate the community's contribution to and resistance to activity (arrow B), and provide vehicles for top managers to shape 
activity, even as they are shaped by it (arrow C). The interplay between top managers and these practices is strategising" $\mathrm{p}$ (42). Jarzabkowski argues that the framework can be used to identify two types of strategising: procedural and interactive.

Procedural strategising is "the use of formal administrative practices to shape the flow of strategy in an organisation" (p82). It provides structure that helps to lend persistence to a strategic activity, and it also provides diagnostic controls. It confers structural legitimacy, which reinforces the social order displayed in routines, hierarchies and roles (Giddens 1984). Examples of procedural strategising practices include strategic, budget and operating plans, management information systems, key performance indicators, trend analyses, quarterly returns, staff planning systems, and asset utilisation indicators ( $p$ 100).

Interactive strategising is "purposive face-to-face interactions between top managers and other members of the organisational community in order to shape the flow of strategy" (p92). This form of strategising confers interpretive legitimacy by generating frameworks of meaning and normative controls that make individuals' actions mutually intelligible to each other. The top management team uses four different mixes of procedural and interactive strategy. This is demonstrated in a Strategising Matrix, reproduced as Figure 2.

Figure 2: The Strategising Matrix (Jarzabkowski 2005 Figures 7.1 p 161 and 5.1 p 104)

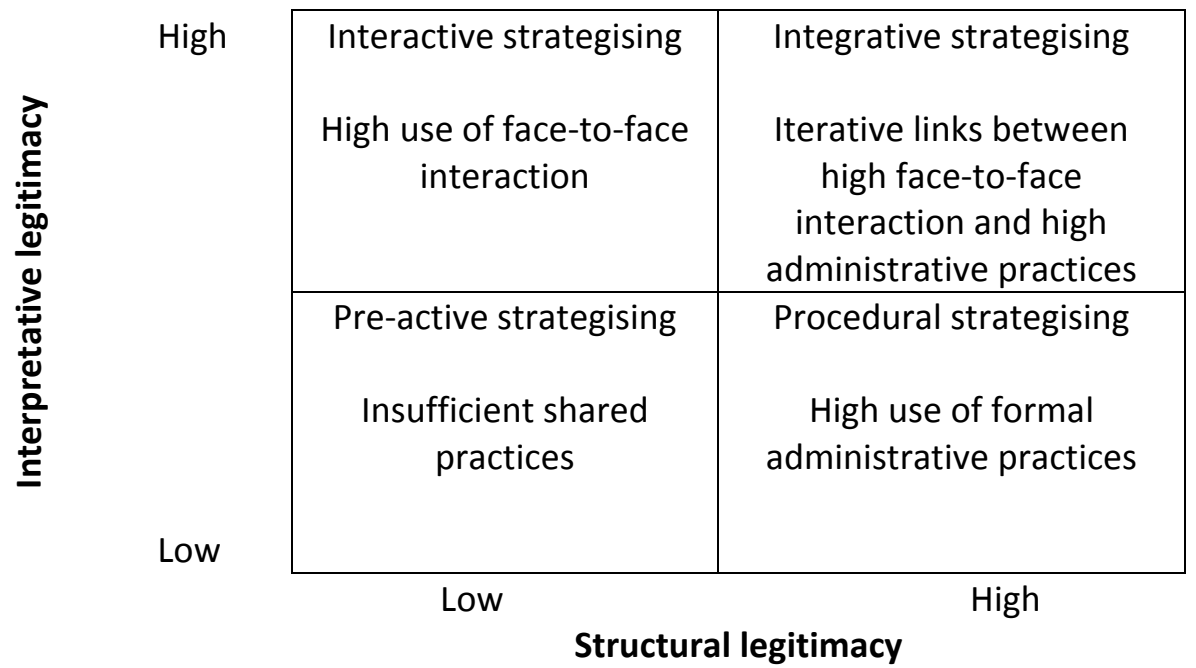

Pre-active strategising describes a practice which is not shared across the organisation. Localised activities are relevant to particular groups of individuals, but those activities do not have the formality to enable them to persist, and therefore have low structural legitimacy. Localised activities also do not have commonly understood meanings shared across the organisation, and hence have low interpretative legitimacy. When procedural strategising predominates, there is high structural legitimacy because activities are embedded in formal practices, but low interpretative legitimacy because the strategic meaning of these activities is unclear. By contrast, interactive strategising has high interpretative legitimacy - its meaning is clear, but it is not embedded in formal practices and therefore may not persist. Integrative strategising occurs when there are iterative links between both types of strategising, and provides both interpretative and structural legitimacy. Over time, types of strategising change, as top managers seek to shape the practices of the organisational community in different ways. 
Types of strategising also vary according to whether a strategy is regarded as "core" to the organisation. According to Jarzabkowski (2005), most organisations have a core strategy, that "in some way embodies what the organisation is about" p134, has inherent legitimacy, and is often associated with procedural strategising. Organisations also have non-core strategies which may require more interactivity to gain organisational support. For example, university communities may see teaching and/or research as core, and commercial activity as non-core.

\section{Activity based theories of development}

Activity-based theories of development conceptualise learning as a social activity. The learner is able to achieve goals, with guidance, that s/he could not achieve unaided. The gap between what can be achieved unaided and what can be achieved with guidance is known as the Zone of Proximal Development. This concept was first applied to learning in children, and defined as: "the distance between the actual development level as determined by independent problem-solving, and the level of potential development as determined through problem-solving under adult guidance or in collaboration with more capable peers" (Vygotsky 1978, 1930). This social, practical approach to learning is contrasted with the more universal concept of "stages of growth" (Piaget 1926), which identifies the same stages of development for all learners, regardless of social context.

Within the Zone of Proximal Development, support for learners can be described by means of a scaffolding metaphor (Wood 1976, Cazden 1979, Stone 1998). Scaffolding describes the specific practices by which the expert or teacher supports the learner. Puntambekar and Hubscher (2005) adapted it to describe support for adult learning in complex environments, and identified recruitment, goal orientation, provision of support, and gradual but not necessarily complete withdrawal of that support as the main scaffolding practices. Recruiting people into a learning activity, and providing goal orientation, occurs via shared understanding of a task. One or more individuals provide support that software tools may enhance. Support generates independent activity on the part of the learner, but some support may be necessary when the learner achieves independence. It should be noted that there has been a different use of the scaffolding metaphor in the IS literature to focus on: "the provisional scaffolding that is erected by the temporary and situated engagement of technology in knowledgeable activity" (Orlikowski 2006 p462). This uses a dictionary definition of "physical scaffolds as they are used in the building industry" p461. It is not used to conceptualise learning, and hence has not been incorporated further into the discussion.

In this paper, concepts from the zone of proximal development and from scaffolding are used to analyse phases of an Enterprise System implementation, and development of the organisation within those phases. These concepts add support to the research framework described below.

\section{Research framework}

The research framework makes three modifications to Jarzabkowski's (2005) activity theory. Figure 3 presents these modifications, which the discussion below explores. The first modification is that there are two subjects to the study. One is the Top Management Team (TMT), as with Jarzabkowski's original study. The second is the team responsible for the way the Enterprise System is used within the organisation - the Enterprise System Custodians (ESC). This team provides technical support, training and documentation and liaises with the organisational community regarding general aspects of Enterprise System use. 
The second modification is an exploration of the relationship of Enterprise System outcomes to multiple strategies. Not all Enterprise System outcomes are strategic. To understand fully how the Top Management Team and Enterprise System Custodians guide the organisational community's use of Enterprise Systems this needs to be taken into account. The way in which the community is motivated to use such systems is likely to be influenced by which strategic goals the system serves, and whether the community regards them as "core"'.

The third modification is that goal directed activity is phased in some way, as the Enterprise System implementation proceeds over time. In keeping with the concept of the Zone of Proximal Development, the exact nature and definition of each phase will be contextual - it will vary from organisation to organisation. However, each phase will see some changes in the practices of the organisational community, as it learns how to use the system for changing strategic needs. This paper uses a modified scaffolding metaphor to investigate how the Top Management Team and Enterprise System Custodians guide that learning.

Figure 3: modifications of Jarzabkowski's 2005 activity theory framework for Strategy as Practice

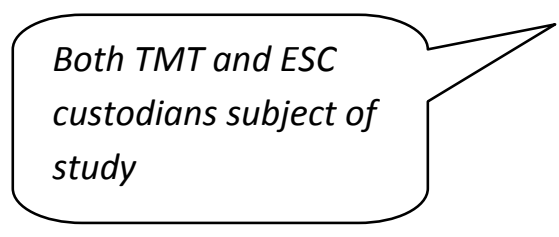

\section{Subject:} Top Management Team

A: Practices constrain and enable interaction with the other about activity

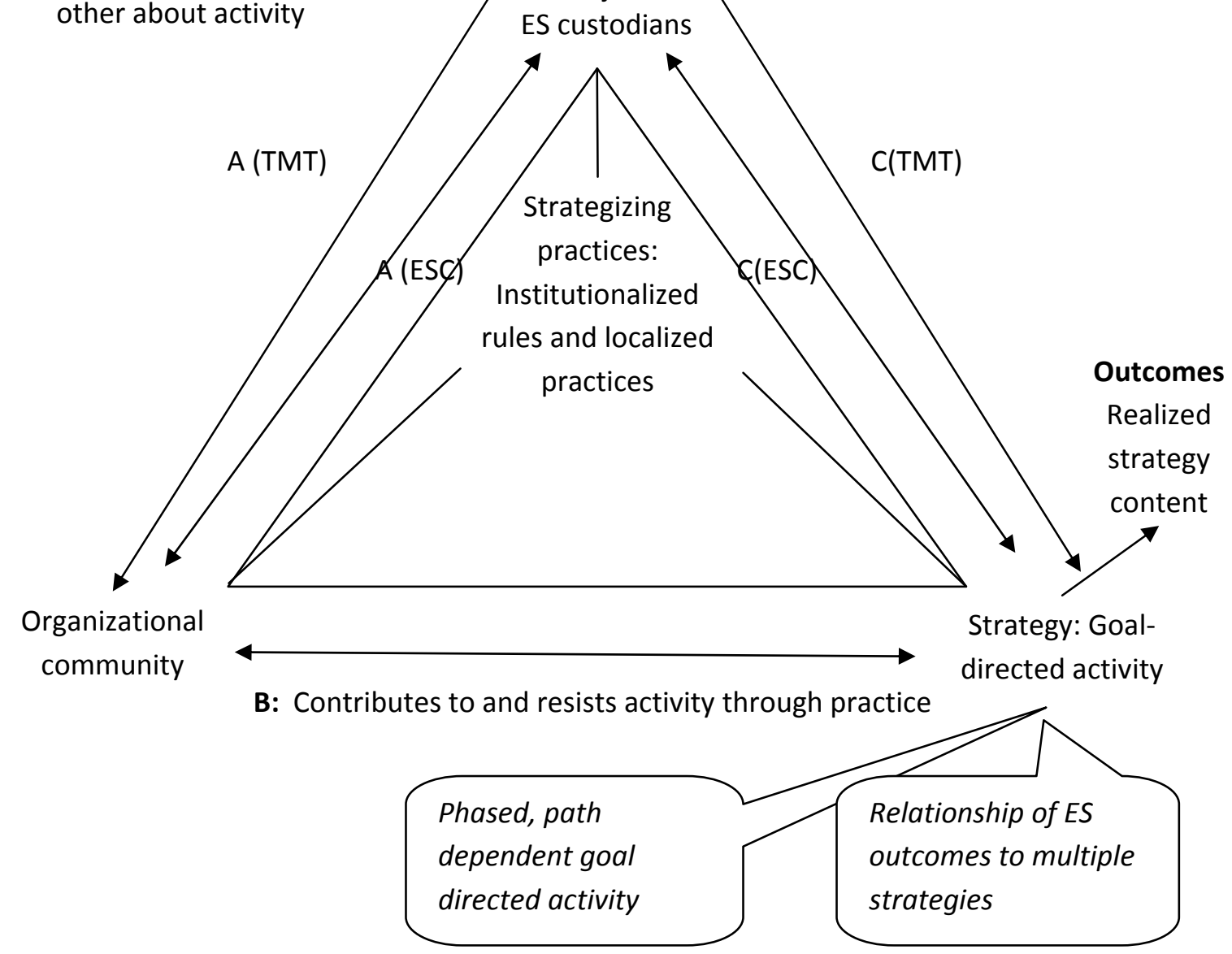




\section{Research Design}

\section{Case study design}

The aim of the study was to identify patterns of activities that remained consistent across organisations even when the specific context of their Enterprise System implementations differed. A case study approach was taken in order to capture the detail implicit in an activity-based approach. Two case studies were used, so that patterns that they had in common could be identified, and compared with their context. Using two case studies had the added advantage that: "evidence from multiple case studies is considered more compelling" (Yin 2003 p 46). The organisations chosen were from the university sector. In common with hospitals and professional service firms, universities have autonomous, professional workforces which may not respond to top-down management, yet need to respond to competitive pressures and external demands (Jarzabkowski 2005). This allowed issues related to the pursuit of multiple, conflicting goals to be explored.

Two universities with broadly similar characteristics were chosen for the study. Both are based in the UK, where universities are estimated to provide $2.3 \%$ of the GDP and $£ 3$ billion in export earnings (Smith and Lambert 2009), and are operating in an increasingly competitive environment (Jarzabkowski 2005 p 70, Browne 2010). Both universities have significant research profiles, but are relatively young. They are therefore heavily reliant on activities that maintain their market position, unlike more established universities, which can rely to some extent on historical reputation and on financial endowments. Also, unlike universities with less of a research profile, they could not focus on teaching alone and attract students based on low cost. Both universities described this as being part of the "squeezed middle" (Registrar, University 1, Director Strategic Planning, University 2). Both universities are relatively small - one university has about 10,000 full-time students and the other about 13,500. Both universities have four Faculties/Schools, which retain considerable autonomy.

Both universities also run the same student administration system. This system lies at the core of the University Enterprise System suite. It has a large range of functionality, supporting the full student lifecycle from first application to maintenance as an alumnus, recording and managing curriculum, and providing extensive reporting facilities within challenging governance regimes. It also needs to keep records in perpetuity of both students and curriculum. It is hence very large, and yet has a relatively small customer base. There has been a long, fairly troubled history of student administration systems development and implementation. Several countries have tried a consortium-based approach, with mixed success (Berglund 1994, Baumber and Mullarvey 2000, Vitale 2000, Nurmi et al 2011, LADOK 2013). Many countries are now serviced by a small number of vendors. Most universities in Australia use one of three vendors, for example: (Callista 2013, Oracle 2013, Technology One 2013). The UK is served by different systems (SITS 2013, Banner 2013). All Danish Universities use one vendor (STADS 2013). Other applications within the Enterprise System suite - for example HR and Finance - share broad similarities with those used in other organisations, and hence are used by a much broader customer base. 


\section{Data collection}

Interviews were conducted with members of the top management team, the Enterprise Systems custodians, and senior administrators representing the organisational community. The interviews were semi-structured, and designed to capture interviewees' experience and observations regarding Enterprise Systems. All interviews were conducted under conditions of anonymity, by one of the authors, who was the only person to have access to the results for data analysis. The interviews were conducted at two distinct points in time: January - February 2011, and September - October 2011, and on each occasion, appropriate documents were collected. Interviews were about an hour in length, and were recorded and transcribed. Initial descriptive coding of the data from the January - February interviews, as discussed in the following analysis section, led both to further interview questions, and to the identification of further interviewees for the September-October interviews.

Table 2 lists interviewees, and Table 3 the key documents.

Table 2 Interviewees at the two case sites

\begin{tabular}{|c|c|}
\hline University 1 & University 2 \\
\hline \multicolumn{2}{|c|}{ Top Management Team } \\
\hline Academic Registrar and Director of Planning (2) & Academic Registrar \\
\hline \multirow[t]{3}{*}{ Chair, Student Systems Steering group } & Finance Director \\
\hline & Director of Planning (2) \\
\hline & Director IT (2) \\
\hline \multicolumn{2}{|c|}{ Enterprise System custodian team } \\
\hline Information Systems Group member & Student Systems Project Manager (2) \\
\hline \multirow[t]{2}{*}{ Information Systems Group member (2) } & Group Leader, Process Change and Development \\
\hline & Information Manager (2) \\
\hline \multicolumn{2}{|c|}{ Senior administrators, representing the organisational community } \\
\hline Examinations officer - Central University & Dean, Business, Economics and Law (2) \\
\hline Project Manager, Careers Service & $\begin{array}{l}\text { Administrative Head, Business, Economics and } \\
\text { Law }\end{array}$ \\
\hline $\begin{array}{l}\text { Administrative Head, Languages and Social } \\
\text { Sciences }\end{array}$ & $\begin{array}{l}\text { Student Systems Expert, Business, Economics } \\
\text { and Law }\end{array}$ \\
\hline \multicolumn{2}{|l|}{ Undergraduate examinations manager, Business } \\
\hline \multicolumn{2}{|l|}{ Postgraduate examinations manager, Business } \\
\hline \multicolumn{2}{|l|}{$\begin{array}{l}\text { Head of Undergraduate Progammes, Engineering } \\
\text { and Applied Sciences }\end{array}$} \\
\hline \multicolumn{2}{|c|}{\begin{tabular}{|l|l} 
Administrative Head, Life and Health Sciences & \\
\end{tabular}} \\
\hline \multicolumn{2}{|c|}{ Total interviews 28 (interviewees 21) } \\
\hline $13(11)$ & 10(15) \\
\hline
\end{tabular}

Note: Generic titles have been used for all positions, and the name Faculties/Schools has been used for either entity, to preserve anonymity 
Table 3: Key documents at the two case sites

\begin{tabular}{|c|c|}
\hline University 1 & University 2 \\
\hline \multicolumn{2}{|c|}{ Student administration implementation } \\
\hline Post implementation review (2005) & $\begin{array}{l}\text { Final Project Summary and Report for Project } \\
\text { Board (2008) }\end{array}$ \\
\hline Start and end dates to be recorded (2010) & Post implementation review (2010) \\
\hline \multicolumn{2}{|c|}{ Systems improvement initiatives } \\
\hline Description, portal initiative (2007/8) & Business Intelligence project (2011) \\
\hline \multicolumn{2}{|l|}{ Powerpoint slides, portal strategy summit (2009) } \\
\hline \multicolumn{2}{|l|}{$\begin{array}{l}\text { Powerpoint slides, significant portal } \\
\text { developments }(2009 / 10)\end{array}$} \\
\hline \multicolumn{2}{|l|}{ Planned word and priorities (example list) (2011) } \\
\hline \multicolumn{2}{|l|}{$\begin{array}{l}\text { Development proposal list, based around key } \\
\text { activities in the student lifecycle (2010) }\end{array}$} \\
\hline \multicolumn{2}{|l|}{$\begin{array}{l}\text { Student Administration System Activity report } \\
\text { (2010) - example }\end{array}$} \\
\hline \multicolumn{2}{|l|}{ Admissions process maps (2011 - from intranet) } \\
\hline \multicolumn{2}{|c|}{ Formal strategic plans and reviews } \\
\hline \multirow[t]{2}{*}{ KPIs for Council (2011)- update of $2008 \mathrm{KPIs}$} & $\begin{array}{l}\text { University plan (2009/10) (including Balanced } \\
\text { Scorecard review for 2009) }\end{array}$ \\
\hline & $\begin{array}{l}\text { University Strategy and four year plan (2011) } \\
\text { (includes four year rolling plan) }\end{array}$ \\
\hline \multirow[t]{2}{*}{$\begin{array}{l}\text { Strategic plan for } 2020 \text { (public document - } \\
\text { reference suppressed to maintain anonymity) }\end{array}$} & $\begin{array}{l}\text { Research strategy 2007-2012 (public document - } \\
\text { reference suppressed to maintain anonymity) }\end{array}$ \\
\hline & Diagram - structure of IT Strategy (2011) \\
\hline \multicolumn{2}{|c|}{ Pan University forums } \\
\hline $\begin{array}{l}\text { Cross University forum notes - communication } \\
\text { with students ( } 2010 \text { ) (other fora have been held } \\
\text { on automation of student management } \\
\text { processes, and general reporting/progress) }\end{array}$ & $\begin{array}{l}\text { Powerpoint presentation given by Vice } \\
\text { Chancellor to University Managers on the } \\
\text { University Strategy and Plan update }\end{array}$ \\
\hline \multicolumn{2}{|l|}{$\begin{array}{l}\text { Process review - Student Entry (2010) } \\
\text { two day process mapping involving } 52 \text { staff } \\
\text { - Overview document } \\
\text { - Powerpoint introduction } \\
\text { - Detailed process reviews for six different } \\
\text { types of students }\end{array}$} \\
\hline \multicolumn{2}{|l|}{$\begin{array}{l}\text { Process review - Student Assessment (2010) } \\
\text { two day process mapping initiative } 40 \text { staff } \\
\text { - Overview document } \\
\text { - Powerpoint introduction } \\
\text { - } \quad \text { Detailed process reviews for five parts of the } \\
\text { assessment process }\end{array}$} \\
\hline \multicolumn{2}{|c|}{ Public documents for background (references suppressed to maintain anonymity) } \\
\hline Organisational structure - University & Organisational structure - University \\
\hline HR Strategy & $\begin{array}{l}\text { Press release announcing new Vice Chancellor } \\
(2004)\end{array}$ \\
\hline Introductory brochure & Annual Review $(2010,2006 / 7)$ \\
\hline Report on new lecturers' strategy & \\
\hline
\end{tabular}




\section{Analysis}

Analysis involved iterative coding (Miles and Huberman 1994) with five main stages. The transcripts from the first set of interviews were edited into notes with headings for each of the concepts, themes and issues identified by both the interviewer and the interviewee. These notes were returned to the interviewees, who in two cases suggested minor changes. For each site, an informal internal report was written based on the interviews and document analysis. This was circulated to interviewees. The second round of interviews included extended interviews with previous interviewees, and the inclusion of new interviewees. Descriptive coding was also undertaken on the second set of interviews.

The second stage of coding involved identification of distinct phases at each university. These phases were characterised by distinct practices by the organisational community at the beginning and end of each phase, and by distinct activities by top managers and enterprise system custodians in guiding those practices.

The third stage of analysis explored the first research question:-

How are Enterprise System practices related to the multiple strategies of the organisation?

Strategies for the University as a whole were identified. The aim was to identify the emerging strategies which informed the practices of the top management team, the Enterprise System custodians, and the organisational community they were guiding. In order to do this, documents on strategies and transcripts of interviews were compared - while formal written strategy was a key data source, it was not assumed that it was the same as emerging strategy. The four strategies identified by Jarzabkowski (2005) were used as a starting point, and modified as the analysis proceeded.

At each phase, Enterprise System related activities were identified, and classified, using previous literature (Davenport et al 2004, Seddon et al 2010) according to whether they mainly affected data integration, process optimisation or management information (MI). The effect of these practices on strategies, whether positive, negative, or unknown, was coded. See Table A.1 in the Appendix that indicates how this coding was done.

The fourth stage started to explore the second research question:-

How do the activities of the Top Management Team and Enterprise System custodians guide the organisational community with regard to evolving Enterprise System practices?

At each phase, the activities of the Top Management Team were categorised as either procedural or interactive strategising, using Jarzabkowski (2005)'s framework. Each phase was then characterised using the strategising matrix, as pre-active, mainly interactive, mainly procedural, or integrative.

The fifth stage continued to explore the second research question. It categorised the support for learning provided by both the Top Management Team and the Enterprise System custodians. The codes used for this categorisation were derived from those in the scaffolding literature (Wood et al 1976, Stone 1998, Puntambekar and Hubscher 2005). After much iterative coding, the following definitions of scaffolding practices were developed. 
- Recruitment: of individuals from the organisational community willing and able to learn about and use the Enterprise Systems.

- Goal orientation: motivating recruited individuals, and providing mechanisms for them to motivate others in their community.

- Guided support: providing support for recruited individuals by means of different mechanisms.

- Encouraging fluidity: this relates to the concept of increased independence of use. In the context of this study, it was found to include activities which encouraged the awareness of processes and data to not only use the system, but be able to develop new uses as strategic needs changed; in other words, ensuring that system use remained fluid.

The activities identified for each practice were used to populate Table A.2. This was done for each phase. Table A.2 also described the nature of strategising predominant during the phase.

\section{Results summary}

Detailed results for each university are given in the Appendix and summarised here. For each university, specific phases of activities supporting the progressive implementation and use of the Enterprise System are identified, together with the context in which they occur. For each phase, the ways in which the Enterprise System supports core and non-core strategies are discussed. The nature of strategising at each phase - pre-active, interactive, procedural or integrative - is identified, as are the scaffolding activities of recruitment, goal orientation, guided support, and encouraging fluidity.

\section{University 1}

Four phases were identified at University 1. Phase 1, which occurred in 2002, involved the selection of a new system. At that time, the university used a central system for statistical returns, and faculties/schools used their own separate systems. System II (implementation, 2002 - 2004) had two main stages, the first of which involved the replacement of the central system. Stage 2 saw the system gradually introduced into some faculties/schools. Phase III (consolidation, 2005 - 2006) involved extending use of the system to all faculties/schools, and introducing a management reporting suite. Phase IV (current use, 2007 onwards) included development of a portal, major reviews of processes and data, and the development of management information suites.

The university structure overall has remained relatively stable through all these phases, retaining most of its key top managers and Enterprise System custodians. The external environment in which the university operates has become significantly more competitive, particularly during Phase IV. Funding has been reduced, and changes in regulations have allowed more competition. The statistical returns required by government have become more complex, and information from those returns is now made available to students to help inform their choice of university (HEFCE 2013a).

The organisational community identified two strategies as "core": research, and the student learning experience. Three "non-core" strategies were also identified: the student administrative experience, government compliance, and administrative effectiveness. The Enterprise System supported "noncore" activities during all four phases, as Table A. 3 in the Appendix indicates. It was only in Phase IV (current use) that some indirect links with "core" strategies were also established. This was largely 
because of the portal which gave both academics and students access to integrated data. The increased competitive pressures during Phase IV resulted in "non-core" strategies becoming more important to survival, and the Enterprise System hence playing a more strategic role in the organisation.

Patterns of strategising and scaffolding during each phase are summarised in Table A.4 in the Appendix. During Phase I (system selection), top managers used interactive strategising to involve the broader community in selecting a system for university-wide use. During phase II stage 1 (central system implementation) top managers' strategising was predominantly procedural, using a formal project management methodology. Recruitment was formalised in project and governance structures, in which top managers explicitly identified "champions" to support the broader community. This stage proceeded very quickly, because the old, central system needed to be replaced before the manager supporting it retired. Tight timelines during this stage limited system fluidity, as data was transferred to the new system with insufficient consideration of the potential of the new system. In Phase II stage 2 (system implementation in some faculties/schools) top managers took a more interactive approach. They established the principle that recruiting members of the organisational community into using the system should be done by persuasion, rather than mandating system use. Enterprise System custodians oriented members of the organisational community towards the goal of using the system by demonstrating its benefits. Fluidity in system use remained, because only those individuals who wanted to use the system did so, but the use of the system was limited to less than half the community. Phase III (consolidation) saw the gradual extension of system use, still using persuasive means. Top managers worked interactively with the Enterprise System custodians, allowing them to operate as a self-managing team, identifying new champions, and extending the use of the system to new areas.

In Phase IV (current use), top managers became increasingly proactive regarding the system. They now complemented their interactive strategising with procedural initiatives - in other words, practised integrative strategising. They used process reviews and small organisational restructures to develop and formalise current "champions" and recruit new ones, working closely with the Enterprise System custodians in doing so. They explicitly became involved in goal orientation via a cultural change initiative "University 1 First" which encouraged the organisational community to prioritise the University over individual faculties/schools, and provided the underpinning for using the Enterprise System to support coordinated processes. For the first time, top managers mandated system use, particularly regarding the provision of data for Government statistics. Enterprise System custodians used the portal to provide guided support. The software supporting the portal allows processes to be coded as "tasks", hence facilitating the correct use of the system but also potentially risking rigidity, by making such processes hard to change. To reduce this risk and encourage fluidity, Enterprise System custodians taught "champions" to code "tasks" relevant to their own area, hence giving them the skills they required to support further change. Top managers and Enterprise System custodians acknowledged that continued fluid use of the system depended on supporting and educating "champions". They also acknowledged that this alone was insufficient and that some errors in system use would continue to occur since some users had neither the motivation nor the skills to use the system correctly. Enterprise System custodians would need to compensate for such errors. 


\section{University 2}

A new student administration system was selected at University 2 in 2004 (Phase I, system selection). At that time, the university had a central system for statistical returns, and separate systems in faculties/schools. During Phase II Stage 1 (2004 - 2005, central system implementation) the central system was replaced. Phase II Stage 2 (2008, faculty/school system implementation) involved the mandatory replacement of all faculty/school systems. Phase III (2009-2010, review) consisted of a review and recommendations for the future. Phase IV (2011 onwards, current use) included several activities to ensure the system was embedded, and also saw some initial developments of a student portal.

Significant organisational change has occurred during these phases. A new Vice Chancellor arrived in 2005, and initiated a major restructure which reduced the number of Faculties/Schools from eight to four, albeit still with considerable autonomy. He also appointed three new Deputy Vice Chancellors, a Registrar, and Directors of Finance, Corporate Services, and Human Resources. The Director of IT had been appointed just before the Vice Chancellor arrived, and has remained in place throughout the implementation.

University 2 identified research and the student learning experience as core strategies, and the student administrative experience, government compliance, growth and administrative effectiveness as non-core strategies. The relationship between the Enterprise System and "core" and "non-core" strategies is shown in Table A.5 in the Appendix. For Phase I (system selection) and the first stage of Phase II (central system implementation), the Enterprise System was seen as supporting one, non-core strategy only: that of government compliance. From Phase II stage 2 (faculty/school system implementation) onwards it was also seen as supporting administrative effectiveness directly, by coordinating processes in faculties/ schools. The management information system provided indirect support for administrative effectiveness, and also for research and the student learning experience, by providing Key Performance Indicators in an appraisal system used for all staff. In Phase IV (current use) statistics derived from Enterprise System data were used on Government and other web sites specifically designed to help students choose the University they wish to attend (HEFCE 2013a). The system thus directly affected the strategy of growth. The self service portal for students directly affected the student administrative experience, and had indirect effects on their learning experience. University 2 has experienced increasing competitive pressure since Phase II stage 2, and the Enterprise System has been seen as strategic since then.

Table A.6 in the Appendix shows the patterns of strategising and scaffolding. Phase I (system selection) was pre-active. The Registrar at the time deliberately limited the scope of the system to replacement of system functionality. Phase II stage 1 (central system implementation) was also preactive: the central system was replaced without significant involvement of the broader organisational community. Phase II stage 2 (Faculty/School system implementation) occurred against the background of restructuring and significant staff changes, and involved a radical change of scope. Top managers used procedural means to mandate use of the new system across all faculties/schools. They used formal project management methodologies for this, but did not always successfully recruit people into using the system, nor orient them towards the goal of using it well. Enterprise System custodians met frequently with faculty/school members to discuss system use, but the predominant form of guided support was a large formal training campaign. People either did not attend, however, or did not absorb, the training. This led to significant problems, and 
introduced rigidities into the system. Existing, complex procedures were coded into the system, allowing little room for further change. Further, because staff did not understand the system there were often problems with the quality of data entered. Eventually, the Enterprise System custodians became concerned enough to request a delay in the "go-live" date, which top managers granted. The system went live across the university more than a year later than expected. Phase III (review) was largely procedural. Top managers stopped all further development and commissioned a formal review. As a result of the review they recommended that a shared vision for the system be developed, that there be a university-wide review of processes, and that all projects use a formal project management methodology and involve members of the senior executive. Phase IV (current use) saw the commencement of further systems development. Top managers used integrative strategising, coordinating the procedural mechanisms developed in Phase III (review) with a more interactive approach. There was increasing emphasis on the recruitment of system experts in organisational areas as a means of improving system use. This was done both informally, by interactive discussions that identified individuals responsible for pockets of best practice, and formally, by small restructures. The Vice Chancellor became personally involved in goal orientation, delivering briefings to staff on the need for process change, including appropriate Enterprise System use to support the strategies which would ensure the university's survival. Enterprise System custodians were increasingly able to orient staff towards the goal of using the system well as the benefits of using it became apparent. The first student portal initiatives - for on-line reenrolment were successful, and the extensive use of Key Performance Indicators provided strong motivation for individuals to make sure that data related to the measurement of their own work was up to date. Enterprise System custodians provided guided support within a clear project governance framework. An emphasis on educating the community towards the advantages of speaking a common language via appropriate standardisation helped to ensure fluidity of ongoing system use. It was recognised, however, that support for system use, and correction of mistakes would always be required, as some staff might not have the motivation or time to use the system correctly.

\section{Discussion}

The two Universities have implemented the same system in different contexts. University 1 started implementing the system earlier than University 2, when there was less commercial pressure on the sector. University 1 also implemented the system within the context of relative structural stability, whereas University 2 underwent considerable structural change in parallel with the implementation. The phases at each university showed different patterns of strategising by the top management team. These affected the extensiveness and fluidity of system use, as Figure 4 shows. 
Figure 4: Patterns of strategising and extensiveness and fluidity of system use.

University 1

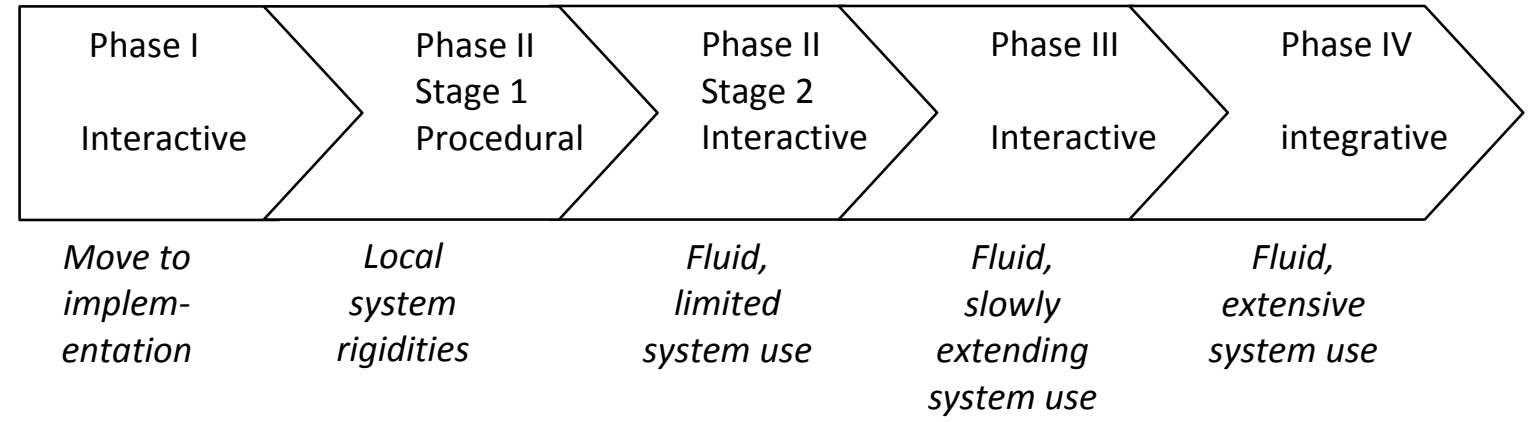

University 2

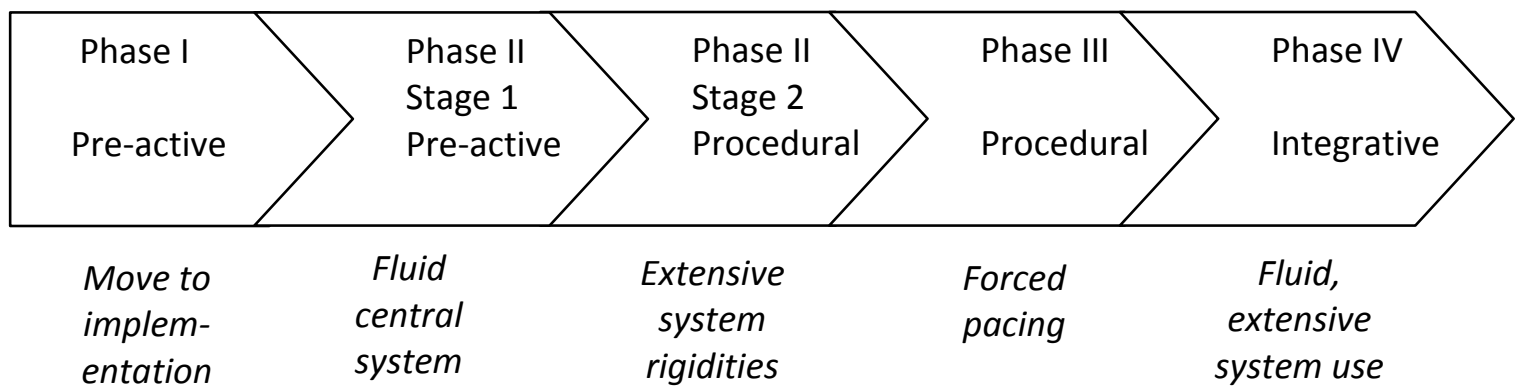

The top management team at University 1 , with its relative stability, had a highly interactive relationship with the organisational community, which affected the nature of each phase. An interactive approach during Phase I (system selection) informed the breadth of governance and importance given to "champions" which was retained during subsequent phases. Phase II Stage 1 (central system implementation), saw, uncharacteristically, a predominance of procedural strategising. Project management methodologies and tight deadlines resulted in the introduction of some local system rigidities, arising from a lack of analysis of data as it was migrated between systems. Phase II Stage 2 (Faculty/School system implementation) reverted to an interactive approach, as did Phase III (consolidation), which meant that the rollout of the system was slow, but the system remained reasonably fluid because people who used the system largely wanted to do so and learnt how to use it well. During Phase IV (current use), system use became more extensive, supported by procedural initiatives, such as process reviews and mini-restructures, which were integrated with the ongoing interactive strategising.

University 2 experienced significant organisational change, which affected the pattern of phasing. In Phase I (system selection), the involvement of the organisational community was deliberately limited - strategising was pre-active. This pre-active strategising was continued into Phase II stage 1 (central system implementation), and resulted in a successful, fluid central implementation, again with limited organisational involvement. Phase II stage 2 (Faculty/School system implementation) saw a very large change in scope - not only were Faculties/Schools expected to be involved, procedural means were used to mandate system use. This introduced rigidities that were of major concern, as people forced to use the system did so without understanding how to use it well. Phase 
III (review) introduced procedures, not to roll out the system, but to change the way in which that rollout proceeded. This has resulted in a more integrative approach in Phase IV, allowing for the already extensive system use to become more fluid in nature.

Comparing phases between the two Universities in this way allows patterns to surface. University 1 had several interactive phases, and University 2 had two pre-active phases. Pre-active and interactive phases were associated with fluid, limited use of the system. Both Universities have had phases of procedural strategising. Procedural phases have been associated with the speedy introduction of the system, but have introduced rigidities. Both Universities are currently using integrative strategising, and this is associated with extensive use of the system in ways which allow it to retain its fluidity.

The relationship of the Enterprise System to the multiple strategies at each University helps to explain the nature of each phase. For both universities, the Enterprise System was seen as supporting the largely non-core strategies of student administrative experience, government compliance and administrative effectiveness. As commercial pressures have increased, so has the importance of these non-core strategies, and hence the strategic importance of Enterprise Systems. Phases I to III at University 1 were implemented when there was less commercial pressure than there is now. This partially explains the interactive approach, which allowed change to occur without a great sense of urgency regarding the pace. As the importance of the system has grown, so has the more integrative strategic approach at University 1 . The commercial pressures experienced at University 2 during Phase II stage 2 partly explain the use of procedural strategising to force what was regarded as urgent change, held in check in Phase III only when the long term implications for system fluidity were recognised.

The way in which fluidity is encouraged is complex. It involves the activities of the top management team (TMT) and enterprise system custodians (ESC) as they work together to guide the organisational community towards fluid system use. Patterns in their activities can be identified using the metaphor of scaffolding. As Figure 5 illustrates, the scaffolding metaphor identifies four main practices: Recruitment of champions, Goal orientation of champions and the broader community, Guided support, and Encouraging fluidity. Each practice is discussed in the following paragraphs. 
Figure 5: Scaffolding activities of the Top Management Team (TMT) and Enterprise System Custodians (ESC)

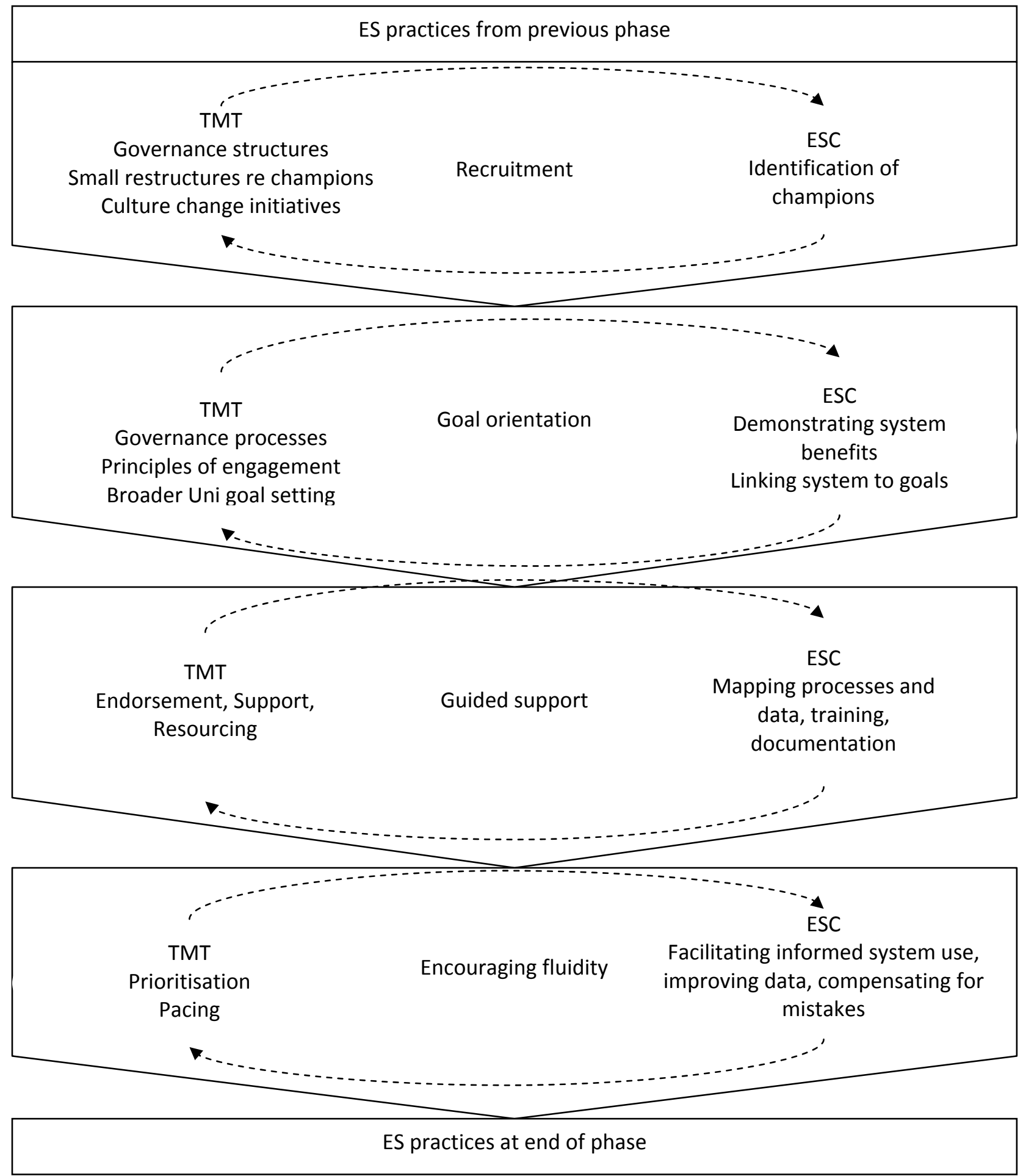

Both universities recognised the importance of recruiting individuals who were willing and able to learn about the system: to understand how it could be used to support processes, and what data it required and stored. These individuals were called "champions" in University 1 and "systems experts" in University 2. For the purposes of this discussion, they are given the same name - 
champions. In both universities the top managers and Enterprise System custodians worked together in identifying these individuals and putting them in positions where they could perform the role of champions. Individuals were sometimes identified as champions informally, and small restructures and process reviews designed around them. At other times there were more formal initiatives. Both universities, for example, created positions in Faculties/Schools that reported to the centre for the express purpose of ensuring a more integrated approach to data and processes. Both universities implemented formal process reviews which often helped identify champions.

In both universities, the top management team oriented members of the community, particularly the champions, towards the goal of using the Enterprise System to support strategic ends. This involved motivating the community to use a system that supported strategies that were perceived as "non-core". Both universities used governance processes regarding implementation, to help provide the strategic context for the system. The top management team at both universities set the use of the system in the context of broader goals - at University 1 there was a "University 1 First" campaign, and at University 2, strategic briefing sessions by the Vice Chancellor. The top management team established principles of engagement. In early phases these diverged between the two Universities, with University 1 establishing principles of persuasion, while University 2 mandated system use. More recently there has been some convergence: University 1 now sometimes mandates system use, while University 2 places greater emphasis on persuasion.

Guided support comes mainly from the Enterprise System custodians, and includes mapping processes and data with members of the organisational community, and providing documentation and training. At both Universities these activities are now highly interactive in nature, with frequent visits from the Enterprise System custodians to Faculties/Schools. The main roles of the top management are to endorse, support and resource these activities.

Encouraging fluidity involves a set of activities that both Universities now see as key to the success of their system use. Specifically, organisational learning must keep pace with system rollout. This essentially means managing the pace of system implementation and development in such a way as to ensure the system is used by process- aware individuals, who see themselves as responsible for the data they create, and can change their use of the system as their needs change. Different mechanisms of pacing were used at the two sites. At University 1, Enterprise System Custodians ensure that system use and development occurs, mainly, when champions have been identified, and in the context of process change. This has been the case since the first rollout to the faculties/schools, and continues now, with the portal development being prioritised in those areas where champions are ready to become involved, and, indeed, to learn to develop the portal themselves. The top management team supports this prioritisation. At University 2, an initial mandatory rollout was identified by the Enterprise System custodians as causing rigidities. They suggested that this be managed by pacing - specifically, a delay in the "go-live" date until the organisation had become more process-aware. This was supported proactively by the top management team who not only granted this delay, but instituted a review of the implementation. System development and use now specifically proceeds using champions, and in the context of process change. An additional activity which encourages fluidity is review of data, normally undertaken by the Enterprise System custodians, to ensure that it is accurate, complete and intuitively described. 
At both organisations it was also recognised that there are some people who, quite simply, will never use the system correctly. This is as a direct consequence of the multiple strategies of the organisation - people recruited to be good researchers and teachers may have neither the aptitude nor the inclination to use the system. A number of mechanisms are used to deal with this.

Mandating use of system data, for example, can improve usage. However an important part of ongoing system fluidity includes compensating for incorrect use of the system.

\section{Conclusion}

By using a Strategy as Practice lens, this paper makes three contributions to our understanding of Enterprise System implementation and use. The first contribution is to link the predominant type of strategising during each phase of an implementation to extensiveness and fluidity of system use. When pre-active or interactive strategising predominates, the system is mainly used by those individuals who want to do so and are willing to learn to use the system well. It hence retains its fluidity, but may only be used by a small portion of the total organisational community. When procedural strategising predominates, by contrast, the system is used extensively, but system rigidities may occur because it may be used without understanding. Only by integrative strategising can the top managers of an organisation ensure that its Enterprise Systems are used extensively and retain the fluidity to support emerging strategy. This contributes to understanding some aspects of an organisation's IS capability (Peppard and Ward 2004, Ward 2012) by drawing attention to the links between IS knowledge and the flexibility of the IS infrastructure. It unpacks the way in which managers strategise (Galliers 2007, 2011), modelling how they use both deliberate, procedural mechanisms and more emergent, interactive means to fulfil strategic IS goals. It also recognises the contextual nature of Enterprise Systems (Howcroft et al 2004, Wagner et al 2005), by describing phases in contextual terms.

The second contribution is to recognise that the relationship between organisational strategy and Enterprise Systems is complex, and changes over time (Markus and Tanis 2000, Davenport et al 2004, Lee and Myers 2004, Wagner and Newell 2007). Specifically, the paper explains how top managers' choice of strategising is related to the perceived strategic importance of the system. In organisations with multiple strategies, Enterprise Systems may predominantly support "non-core" strategies which only become important in a highly competitive environment. Where competitive pressures are low, top managers may rely on pre-active or interactive strategising to drive a slow system rollout. If commercial pressures increase, so does the importance of using the system, and procedural strategising increases. To ensure continued response to evolving commercial pressure, integrative strategising is required.

The third contribution is to explain how both top managers and Enterprise System custodians support organisational learning. A scaffolding metaphor identifies patterns in their activities. They work together to recruit champions from the broader organisational community into learning about the system; provide goal orientation to motivate champions and the community in which they operate; provide support for learning; and encourage fluidity of use by ensuring that the rate of learning keeps pace with the rate of implementation. This contribution extends understanding of organisational learning and the transfer of knowledge between enterprise custodians and the organisational community (Robey et al 2002, Volkoff et al 2004, Srivardhana and Pawlowski 2007). 
In addition to contributing to research on Enterprise Systems, this paper also reinforces and extends concepts in the Strategy as Practice literature. Jarzabkowski's (2005) concepts of procedural and interactive strategising have been applied to phases of an Enterprise System implementation. The relationship between activity theory and Strategy as Practice, already identified (Jarzabkowski 2005 and 2010), has been extended to incorporate activity theory- based models of learning (Vygotsky 1978).

The paper also has implications for practice. It could contribute to a more nuanced view of implementation methodologies; one which would embed context in descriptions of phases. It also stresses the importance of interactions with the community to support procedurally based project plans and governance structures. Without such interaction, the system being implemented may not remain fluid enough to support subsequent organisational change.

This paper has the potential to improve our understanding of Enterprise Systems in organisations, such as universities, with a professional workforce and multiple goals. It could be consolidated with further case studies in government, financial services, health care, law firms and medical practices, which are likely to have similar problems with legitimising system use. It would also be possible to identify differences in approach for organisations where the Enterprise Systems are likely to be more closely linked to core organisational strategies, as may be the case, for example, in manufacturing industries.

\section{Acknowledgements}

The authors would like to thank Sue Newberry for providing generous academic mentoring and leadership, and the editors and anonymous reviewers for their patient, thorough support and guidance.

\section{References}

Auditor's Reports, V. (2003). Report on Public Sector Agencies: Implementation of RMIT University's Academic Management System.

Banner (2013) "Banner Student" http://www.ellucian.com.au/Solutions/Banner-Student/ accessed $23^{\text {rd }}$ October 2013

Baumber, K. and J. Mullarvey (2000). "From MAC to CASMAC and beyond." Perspectives: Policy and Practice in Higher Education 4(4).

Berente, N., U. Gal and Y. Yoo (2010). "Dressage, control and enterprise systems: the case of NASA's Full Cost Initiative." European Journal of Information Systems 19: 21-34.

Berglund, S. (1994). Consortia - the new way insititutions work together or a new approach to old problems in institutional collaboration. 16th Annual EAIR Forum. Amsterdam, Holland.

Bowker, G. C. and S. L. Star (1999). Sorting things out: classification and its consequences. Cambridge MA, MIT Press.

Brown, S. L. and K. M. Eisenhardt (1998). Competing on the Edge: Strategy as Structured Chaos. Boston, Massachusetts, Harvard Business School Press.

Browne, J. (2010) "Securing a sustainable future for higher education: an independent review of higher education funding and student finance. October 12."

Callista (2013) "Callista: better student management" www.callista.com.au accessed $23^{\text {rd }}$ October 2013 
Cazden, C. B., Ed. (1979). Peekaboo as an instructional model: Discourse development at home and at school. Papers and reports on child language development. Palo Alto, CA, Stanford University, Department of Linguistics.

Davenport, T. H. (1998). "Putting the Enterprise into the Enterprise System." Harvard Business Review 76(4): 121-131.

Davenport, T. H. (2000). Mission Critical: Realizing the Promise of Enterprise Systems, Harvard Business School Press.

Davenport, T. H., J. G. Harris and S. Cantrell (2004). "Enterprise Systems and ongoing process change." Business Process Management Journal 10(1): 16-26.

Dechow, N. and J. Mouritsen (2005). "Enterprise Resource Planning Systems, Management Control and the quest for integration." Accounting, Organisations and Society 30: 691-733.

DEEWR. (2013). "Australian Government: Department of Education, Employment and Workplace Relations." Retrieved 23rd September, 2013, from http://www.deewr.gov.au/Pages/default.aspx. Galliers, R. D. and A. R. Sutherland (1991). "Information systems management and strategy formulation: the 'stages of growth' model revisited." Journal of Information Systems 1: 89-114. Galliers, R.D. (2007). On confronting some common myths of IS strategy discourse. The Oxford Handbook of Information and Communication Technology. R. Mansell, D. Quah, and R.Silverstone. Oxford UK, Oxford University Press: 225-243.

Galliers, R.D. (2011). Further Developments in information sysems strategizing: unpacking the concept. The Oxford Handbook of Management Information Systems: Critical Perspectives and New Directions. R.D. Galliers and W.L. Currie. Oxford UK, Oxford University Press: 329-345.

Gibson, C. F. and R. L. Nolan (1974). "Managing the four stages of EDP growth." Review: 76-88.

Giddens, A. (1984). The Constitution of Society, University of California Press. Glover, H. (2004). A Comparative Study of University Administrative Systems. PhD, Nottingham. Golsorkhi, D., L. Rouleau, D. Seidl and E. Vaara, Eds. (2010). Cambridge Handbook of Strategy as Practice. Cambridge, UK, Cambridge University Press.

Gomez, M.-L. (2010). A Bourdieusian perspective on strategising. Cambridge Handbook of Strategy as Practice. D. Golsorkhi, L. Rouleau, D. Seidl and E. Vaara. Cambridge UK, Cambridge University Press: $141-154$.

Guardian. (2013). "The Guardian University Guide." Retrieved 23rd September, 2013, from http://www.guardian.co.uk/education/universityguide.

HEFCE. (2013). "Higher Education Funding Council for England." Retrieved 23rd September, 2013, from www.hefce.ac.uk.

HEFCE. (2013a). "Key Information For Students (KIS)." Retrieved September 30th, 2013, from http://www.hefce.ac.uk/whatwedo/lt/publicinfo/kis/

Henkel, M. (2005). "Academic Identity and Automony in a Changing Policy Environment." Higher Education 49(1/2): 115 - 176.

Howcroft, D., S. Newell and E. Wagner (2004). "Editorial: Understanding the contextual influences on enterprise system design, implementation, use and evaluation." Journal of Strategic Information Systems 13(4): 271-277.

Jarzabkowski, P. (2005). Strategy as Practice: an activity-based approach. London, SAGE. Jarzabkowski, P. (2010). An activity-theory approach to Strategy as Practice. Cambridge Handbook of Strategy as Practice. D. Golsorkhi, L. Rouleau, D. Seidl and E. Vaara. Cambridge UK, Cambridge University Press: 127-140.

LADOK. (2013). "The LADOK system." Retrieved 23rd September, 2013, from www.ladok.se. Latour, B. (1987). Science in Action, Harvard.

Latour, B. (2005). Reassembling the Social: An Introduction to Actor-Network Theory. Oxford, UK, Oxford University Press. 
Lee, J. C. and M. D. Myers (2004). "Dominant Actors, political agendas, and strategic shifts over time: a critical ethnography of an enterprise system implementation." Journal of Strategic Information Systems 13: 355-274.

Leontiev, A. N. (1978). Activity, Consciousness and Personality. Englewood Cliffs, NJ, Prentice Hall. Luftman, J. (2000). "Assessing Business-IT Alignment Maturity." Communications of the Association for Information Systems 4.

Markides, C. (1995). Diversification, Re-focusing and Economic Performance. Cambridge, MA, MIT Press.

Markus, M. L. and C. Tanis (2000). The Enterprise Systems Experience - from Adoption to Success. Framing the Domains of IT Research: Glimpsing the Future Through the Past. R. W. Zmud. Cincinatti, $\mathrm{OH}$. , Pinnaflex Educational Resources.

Melville, D. (2009). London Metropolitan University: An Independent Review into the circumstances and issues associated with the clawback of significant funds in 2009. London Metropolitan University.

Miles, M. B. and A. M. Huberman (1994). Qualitative Data Analysis: An Expanded Handbook: Second Edition, Sage.

Miller, H. and H. E. Higson (1996). Secretaries' and Administrators' Work and Social Relations. Society for Research into Higher Education Annual Conference: Working in Higher Education - The Staff Experience. Cardiff, Wales, UK.

Mintzberg, H. and J. A. Waters (1985). "Of Strategies, Deliberate and Emergent." Strategic Management Journal 6: 257-272.

Nurmi, A., P. Hallikainen and M. Rossi (2011). "Emerging evaluation processes in consortium-based outsourced system development." Business Process Management Journal 17(5): 711-731.

Oracle 2013 "Peoplesoft Campus Solutions"

http://www.oracle.com/us/products/applications/peoplesoft-enterprise/campussolutions/overview/index.html accessed 23rd October 2013.

Orlikowski, W.J. 2006. Material knowing: the scaffolding of human knowledgeability. European Journal of Information Systems $15460-466$

Orlikowski, W. (2010). Practice in research: phenomenon, perspective and philosophy. Cambridge Handbook of Strategy as Practice. D. Golsorkhi, L. Rouleau, D. Seidl and E. Vaara. Cambridge, UK, Cambridge University Press: 23-33.

Peppard, J. and J. Ward (2004). "Beyond Strategic Information Systems: Towards an IS capability." Journal of Strategic Information Systems 13(2): 167-194.

Pettigrew, A. (1985). The Awakening Giant. Oxford, Blackwell.

Piaget, J. (1926). The language and thought of the child. New York, Harcourt, Brace, World.

Porter, M. E. (1980). Competitive Advantage. New York, Free Press.

Porter, M. E. (1985). Competitive Advantage: Creating and Sustaining Superior Performance (with 1998 introduction). New York, The Free Press.

Puntambekar, S. and R. Hubscher (2005). "Tools for Scaffolding Students in a Complex Learning Environment: What Have We Gained and What Have We Missed." Educational psychologist 40(1): 112.

Robey, D., J. W. Ross and M.-C. Boudreau (2002). "Learning to Implement Enterprise Systems: An Exploratory Study of the Dialectics of Change." Journal of Management Information Systems 19(1): 17-46.

Ross, J. W. and M. R. Vitale (2000). "The ERP Revolution: Surviving vs Thriving." Information Systems Frontiers 2(2): 233-241.

Schmidt, E. K., K. Langberg and K. Aaagard (2006). Funding Systems and their effects on Higher Education Systems: Country Study Denmark. Oecd, The Danish Centre for Studies in Research and Research Policy, University of Aarhus.

Scott, J. E. and I. Vessey (2000). "Implementing Enterprise Resource Planning Systems: The Role of Learning from Failure." Information Systems Frontiers 2(2): 213 - 232. 
Seddon, P. B., C. Calvert and S. Yang (2010). "A Multi-Project Model of Key Factors Affecting Organizational Benefits from Enterprise Systems." MIS Quarterly 34(2): 305 - 328.

Sillince, J. A. A. and S. Mouakket (1998). "Divisive and integrative political strategies in the IS adaptation process: the MAC initiative." European Journal of Information Systems 7: 46 - 60. Smith, S. and R. Lambert (2009). Higher education's importance goes well beyond teaching. UK, The Guardian.

SITS (2013) Tribal - SITS: Vision

http://www.tribalgroup.com/TECHNOLOGY/SITSVISION/Pages/default.aspx accessed 23rd October 2013.

Srivardhana, T. and S. D. Pawlowski (2007). "ERP systems as an enabler of sustained business process innovation: A knowledge-based view." Journal of Strategic Information Systems 16: 51-69.

Star, S. L. and J. R. Griesemer (1989). "Institutional ecology, 'translations' and boundary objects: amateurs and professionals in Berkeley's museuem of vertebrate zoology." Social Studies of Science: 387-420.

STADS (2013) "STADS for students" http://www.students.stads.aau.dk/ accessed $23^{\text {rd }}$ October 2013 Stone, C. A. (1998). "The metaphor of scaffolding: Its utility for the field of learning disabilities." Journal of Learning Disabilities 31(4): 334-364.

Technology One (2013) "Education" http://www.technologyonecorp.com/Education accessed 23rd October 2013

Tomblin, M. S. (2010). "Theory Development in Enterprise Systems and Organizational Learning." Journal of Organizational Computing and Electronic Commerce 30: 398-416.

Vitale, M. R. (2000). "Recovering from Software Development." Educause Review.

Volkoff, O., M. B. Elmes and D. M. Strong (2004). "Enterprise Systems, knowledge transfer and power users." Journal of Strategic Information Systems 13(4): 279 - 304.

Vygotsky, L. $(1978,1930)$. Mind in Society: The Development of Higher Psychologial processes. Cambridge MA, Harvard University Press.

Wagner, E.L., D. Howcroft and S. Newell (2005). "Editorial Special Issue Part II: understanding the contextual influences on enterprise system design, implementation, use and evaluation." Journal of Strategic Information Systems 14(2): 91-95.

Wagner, E. L. and S. Newell (2007). "Exploring the Importance of Participation in the PostImplementation Period of an ES Project: A Neglected Area." Journal of the Association for Information Systems 8(10): 508-524.

Ward, J. M. (2012). "Information systems strategy: Quo vadis?" Journal of Strategic Information Systems 21(2): 165-171.

Whittington, R. (1996). "Strategy as Practice." Long Range Planning 29(5): 731-735.

Whittington, R. (2010). Giddens, structuration theory and Strategy as Practice. Cambridge Handbook of Strategy as Practice. D. Golsorkhi, L. Rouleau, D. Seidl and E. Vaara. Cambridge, Cambridge University Press: 109-126.

Wood, D. (1988). How Children Think and Learn: The Social Contexts of Cognitive Development. Oxford, UK, Blackwell.

Wood, D., J. S. Bruner and G. Ross (1976). "The role of tutoring in problem solving." Journal of Child Psychology and Psychiatry 17(2): 89-100.

Yin, R. K. (2003). Case study research: design and methods. Thousand Oaks, Sage. 


\section{Appendix}

\section{Analysis Tables}

Table A.1 illustrates the table populated while coding the relationship between Enterprise System practices and organisational strategies.

Table A.1: relationship of Enterprise System practices to organisational strategies

\begin{tabular}{|c|c|c|c|c|c|c|}
\hline \multicolumn{2}{|c|}{ Expected ES related activities } & \multicolumn{5}{|c|}{ Overall strategies } \\
\hline & & Strategy 1 & Strategy 2 & Strategy 3 & $\ldots$ & Strategy $n$ \\
\hline \multicolumn{7}{|c|}{ Phase $n$} \\
\hline \multirow{3}{*}{ 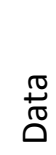 } & Activity 1 & & & & & \\
\hline & ..... & & & & & \\
\hline & Activity $n$ & & & & & \\
\hline \multirow{3}{*}{$\begin{array}{l}\breve{d} \\
\stackrel{0}{0} \\
\stackrel{0}{0}\end{array}$} & Activity 1 & & & & & \\
\hline & ..... & & & & & \\
\hline & Activity $n$ & & & & & \\
\hline \multirow[b]{3}{*}{$\bar{\Sigma}$} & Activity 1 & & & & & \\
\hline & $\ldots$. & & & & & \\
\hline & Activity $n$ & & & & & \\
\hline
\end{tabular}

Table A.2 illustrates the table populated in order to identify patterns of strategising and scaffolding

Table A.2: Patterns of strategising and scaffolding at each phase

\begin{tabular}{|l|l|l|l|l|}
\hline Team & Recruitment & Goal orientation & Guided support & Encouraging fluidity \\
\hline \multicolumn{4}{|c|}{ Phase $\mathrm{n}$ - nature of strategising (preactive, procedural, interactive, integrative) } \\
\hline TMT & & & & \\
\hline ESC & \multicolumn{3}{|l|}{ Phase $\mathrm{n}+1$ - nature of strategising (preactive, procedural, interactive, integrative) } \\
\hline \multicolumn{4}{|c|}{} \\
\hline
\end{tabular}

Key:

TMT Top Management Team

ESC Enterprise System custodians

\section{Results - University 1}

At University 1, the decision to acquire a new system was made at the turn of the century. The selection, implementation and use of the system can be categorised in several phases, as discussed below. The University structure overall has remained relatively stable throughout the phases of the implementation, and has retained many of its key top managers and Enterprise System custodians. There were major restructures in the past, but these ended in 1996 when the then Vice Chancellor resigned. These earlier restructures included major redundancy initiatives, a reduction from twentyfour to nine departments and groups, and subsequent consolidation into four Faculties/Schools.

\section{Phases of implementation and use}

Interviewees and documents identified four Phases at University 1: Phase I, selection of the system, Phase II, system implementation, Phase III consolidation, and Phase IV current use. Before Phase I 
(selection), the University used a central system to produce statistical returns to Government, and process admissions and student records. Access to the system was limited to key members of the Registry and the IT department. The IT manager was the main expert regarding the system, and his decision to retire provided motivation for its replacement. Faculties/Schools used their own administrative processes, and acquired or developed their own systems to support these. Links between the Faculty/School systems and the central one were entirely manual. Phase I was completed in 2002 with the selection of a new system.

Phase II (system implementation) was described by interviewees as having two main stages. The first stage involved the replacement of central admissions processing and government statistical returns. The second stage consisted of the gradual replacement of Faculty/School functionality. By the end of stage 2 one Faculty/School was using the system fairly extensively, and another was using it in processes involving undergraduates. Phase II was completed in 2005 (Post implementation review 2005).

Phase III (consolidation) consisted of extending the use of the system to all Faculties/Schools, and implementing a suite of management reports, many of which were Faculty/School specific. Phase IV (current use) has seen increases in the extensiveness and sophistication of system use. This phase was seen as beginning in 2007 with the development of a portal (Description, portal initiative 2008). This portal continues to be developed for both staff and students, and is a major vehicle for change. Major projects to review processes and data are under way, and management information suites have also been reviewed so that they can be used more generally across the University.

\section{Strategies and the Enterprise System}

This section explores results from University 1 in relation to the research question:

How are Enterprise System practices related to the multiple strategies of the organisation?

Two strategies are seen as core by the organisational community: research, and the student learning experience. This has now been formalised in the Strategic Plan for 2020, but there is evidence that this was the case for the whole of the implementation period. Two other, non-core strategies were identified: government compliance, which both ensures the legal standing of the University and ensures funding, and administrative effectiveness. There was controversy regarding whether student administrative experience for students was part of the core strategy of student learning experience "People have the idea of where administration and learning and teaching either join, or, in fact, there's a gap...there's very much the push for the student experience. They've got to be paying more money, they're already paying more money, and they really should get a very good experience" (Information Systems Group Member 2). To reflect the controversy regarding student administrative experience, it is shown as non-core and separate from learning experience. Table A.3. shows the relationship between phased Enterprise System activities and strategies in University 1. 
Table A.3 : Relationship between phased Enterprise System activities and strategies, University 1

\begin{tabular}{|c|c|c|c|c|c|c|}
\hline \multirow{3}{*}{\multicolumn{2}{|c|}{ Enterprise System activities }} & \multicolumn{5}{|c|}{ Overall strategies } \\
\hline & & \multicolumn{2}{|c|}{ Core } & \multicolumn{3}{|c|}{ Non-core } \\
\hline & & $\begin{array}{l}\text { Res- } \\
\text { earch }\end{array}$ & $\begin{array}{l}\text { Student } \\
\text { learning } \\
\text { exp'ce }\end{array}$ & $\begin{array}{l}\text { Student } \\
\text { admin } \\
\text { exp'ce }\end{array}$ & $\begin{array}{l}\text { Gov't } \\
\text { Comp- } \\
\text { liance }\end{array}$ & $\begin{array}{l}\text { Admin } \\
\text { Effect- } \\
\text { iveness }\end{array}$ \\
\hline \multicolumn{7}{|c|}{ Phase I - system selection pre 2002} \\
\hline Data & Central system for government returns & & & & $x x x$ & \\
\hline \multicolumn{7}{|c|}{ Phase II Stage $1-$ central system implementation $2002-2003$} \\
\hline Data & Central system for government returns & & & & $x x x$ & \\
\hline \multicolumn{7}{|c|}{ Phase II Stage 2 - faculty/school system implementation 2003-2004 } \\
\hline Data & Central system for government returns & & & & $\mathrm{xxx}$ & \\
\hline $\begin{array}{l}\text { Proc- } \\
\text { ess }\end{array}$ & Some faculty/school coordination & & & & & $x x x$ \\
\hline \multicolumn{7}{|c|}{ Phase III consolidation 2005-2006 } \\
\hline Data & Central system for government returns & & & & $x x x$ & \\
\hline $\begin{array}{l}\text { Proc- } \\
\text { ess }\end{array}$ & Significant faculty/school processes & & & & & $\mathrm{xxx}$ \\
\hline $\mathrm{Ml}$ & Faculty/school specific MI & & & & & $x x x$ \\
\hline \multicolumn{7}{|c|}{ Phase IV current use 2007 onwards } \\
\hline \multirow[t]{3}{*}{ Data } & Central system for government returns & & & & $\mathrm{xxx}$ & \\
\hline & Integrated data available to students & & $\mathrm{x}$ & $x x x$ & & $x x x$ \\
\hline & Integrated data available to staff & $x$ & $\mathrm{x}$ & & & $x x x$ \\
\hline \multirow{2}{*}{$\begin{array}{l}\text { Proc- } \\
\text { ess }\end{array}$} & Self-service portal for students & $x$ & $x$ & $x x x$ & & $x x x$ \\
\hline & Staff portal & $x$ & $\mathrm{x}$ & & & $x x x$ \\
\hline $\mathrm{Ml}$ & University-wide management info & & & & & $x x x$ \\
\hline Key & $\begin{array}{ll}\mathrm{xxx}: & \text { direct relationship } \\
\mathrm{x}: & \text { indirect relationship }\end{array}$ & & & & & \\
\hline
\end{tabular}

It is evident from this table that the Enterprise System directly affects non-core strategies only (as shown by the symbol ' $x x x^{\prime}$ in the relevant columns) The indirect relationship between Enterprise System and core strategies (as shown by the symbol ' $x$ ') varies. It may be beneficial in some cases, but detrimental in others. Some examples follow. The introduction of a self-service portal for enrolments and many other processes is seen as entirely beneficial. It improves convenience for students, and reduces costs of administration significantly. In other situations, results may be more mixed. Portal-based submission of student assessments, and processing of marks, for example, may potentially improve students' administrative experience. It requires, however, that academics move away from paper-based marking towards on-line marking. The effect of this change on academics' time commitments, and on the quality of feedback is currently unknown. The process is therefore being piloted.

Notably, the three "non-core" strategies of Government compliance, administrative effectiveness, and student administrative experience have become more prevalent, and more closely linked to the core strategies over time. This is largely because of three changes instigated by government: reduced funding, increased competition due to changes in regulations, and increased complexity of statistical returns. Funding has been cut by about $20 \%$. To balance this, Universities are able to increase their revenue - they have more discretion regarding the number of students they enrol and 
the fees they charge: "the Government's...created a freer market" (Academic Registrar and Director Planning).

Statistical demands are now extremely complex, and include data embedded deeply in the detail of student administration: "We've actually got to give - I think it's 250 fields...for the HESA (Higher Education Statistics Agency)...there's information...down to the [unit of study] level elements that make up the assessments" (Academic Registrar and Director of Planning).

These more complex external demands have increased the strategic nature of the Enterprise Systems. During Phases I and II, the relationship between the Enterprise System and strategy was limited largely to ensuring compliance with what were then relatively simple government returns. Now, extensive, knowledgeable use of the Enterprise Systems is required. Standardisation of some processes has become more critical - for example academics must enter details of assessments in advance of the start of the teaching period in order that statistics can be accurately reported to government. Maintaining research and teaching activities despite funding cuts and increased student numbers increases dependence on the administrative efficiencies that the Enterprise System can bring: "There's been a real clear running up to keep up and everyone's tired. There's been a real drive in the University as a whole to try to automate things, just to make it easier" (Administrative Head, Languages and Social Sciences).

\section{Top Management and Enterprise System Custodian Activities}

In the context of the changing relationship between Enterprise Systems and Strategy, this section discusses University 1 results relevant to the second research question:

How do the activities of the Top Management Team and Enterprise System custodians guide the organisational community with regard to evolving Enterprise System practices?

Table A.4 summarises these results. 
Table A.4 : Patterns of strategising and scaffolding at University 1

\begin{tabular}{|c|c|c|c|c|}
\hline Team & Recruitment & Goal orientation & Guided support & Encouraging fluidity \\
\hline \multicolumn{5}{|c|}{ Phase I - interactive } \\
\hline TMT & $\begin{array}{l}\text { Scene set for } \\
\text { recruitment from } \\
\text { broad organisational } \\
\text { community }\end{array}$ & $\begin{array}{l}\text { Goal implied system } \\
\text { to support whole } \\
\text { community }\end{array}$ & & \\
\hline ESC & & & & \\
\hline \multicolumn{5}{|c|}{ Phase II stage 1 - procedural } \\
\hline TMT & $\begin{array}{l}\text { Faculty/School } \\
\text { "champions" on ESC, } \\
\text { Steering committee } \\
\text { chaired by academic }\end{array}$ & $\begin{array}{l}\text { Goal focussed on } \\
\text { admissions in the } \\
\text { context of a broader } \\
\text { rollout }\end{array}$ & $\begin{array}{l}\text { Tight timelines and } \\
\text { limited budget affect } \\
\text { levels of guided } \\
\text { support }\end{array}$ & \\
\hline ESC & $\begin{array}{l}\text { Formal liaison with } \\
\text { admissions team }\end{array}$ & $\begin{array}{l}\text { Support for } \\
\text { admissions on new } \\
\text { system }\end{array}$ & $\begin{array}{l}\text { Data copied, } \\
\text { procedures matched }\end{array}$ & $\begin{array}{l}\text { Implementation } \\
\text { speed introduced } \\
\text { some rigidities in } \\
\text { data }\end{array}$ \\
\hline \multicolumn{5}{|c|}{ Phase II stage 2 - interactive } \\
\hline TMT & $\begin{array}{l}\text { Principles of } \\
\text { persuasion drove } \\
\text { recruitment }\end{array}$ & $\begin{array}{l}\text { Principles of } \\
\text { demonstrating } \\
\text { system benefits }\end{array}$ & & \\
\hline ESC & $\begin{array}{l}\text { Faculty/School } \\
\text { members persuaded } \\
\text { to use system }\end{array}$ & $\begin{array}{l}\text { System benefits } \\
\text { demonstrated }\end{array}$ & $\begin{array}{l}\text { Processes mapped } \\
\text { and data transferred }\end{array}$ & $\begin{array}{l}\text { Highly interactive } \\
\text { nature helped } \\
\text { knowledgeable use }\end{array}$ \\
\hline \multicolumn{5}{|c|}{ Phase III - interactive } \\
\hline TMT & $\begin{array}{l}\text { Working with ES- } \\
\text { identified champions }\end{array}$ & $\begin{array}{l}\text { Continued } \\
\text { reinforcement of } \\
\text { messages from ESC }\end{array}$ & $\begin{array}{l}\text { Continued support } \\
\text { for ESC as self- } \\
\text { managed team }\end{array}$ & $\begin{array}{l}\text { Support for high } \\
\text { levels of interaction } \\
\text { between ESC and } \\
\text { organisational } \\
\text { community }\end{array}$ \\
\hline ESC & $\begin{array}{l}\text { Identifying } \\
\text { champions }\end{array}$ & $\begin{array}{l}\text { System benefits } \\
\text { demonstrated, } \\
\text { problems with } \\
\text { wrong use of system } \\
\text { becoming apparent }\end{array}$ & $\begin{array}{l}\text { Processes mapped, } \\
\text { data transferred, } \\
\text { Correcting system } \\
\text { misuse }\end{array}$ & $\begin{array}{l}\text { Improving data } \\
\text { quality and access, } \\
\text { educating } \\
\text { champions and } \\
\text { other users }\end{array}$ \\
\hline \multicolumn{5}{|c|}{ Phase IV integrative } \\
\hline TMT & $\begin{array}{l}\text { Process reviews } \\
\text { develop champions } \\
\text { Small organisational } \\
\text { restructures to } \\
\text { formalise positions } \\
\text { of champions }\end{array}$ & $\begin{array}{l}\text { University } 1 \text { First and } \\
\text { culture change } \\
\text { programme. } \\
\text { Mandating system } \\
\text { use. }\end{array}$ & $\begin{array}{l}\text { Support for ESC as } \\
\text { self-managed team, } \\
\text { and for specific } \\
\text { initiatives to embed } \\
\text { process change }\end{array}$ & $\begin{array}{l}\text { Prioritisation of } \\
\text { process change } \\
\text { around champions }\end{array}$ \\
\hline ESC & $\begin{array}{l}\text { Identifying } \\
\text { champions for and } \\
\text { from process } \\
\text { reviews }\end{array}$ & $\begin{array}{l}\text { Processes in line } \\
\text { with University } 1 \\
\text { First direction } \\
\text { System benefits } \\
\text { reinforce process } \\
\text { change }\end{array}$ & $\begin{array}{l}\text { Processes } \\
\text { embedded in portal } \\
\text { 'tasks', improved } \\
\text { access to data, } \\
\text { formal training, } \\
\text { documentation, } \\
\text { correcting system } \\
\text { misuse }\end{array}$ & $\begin{array}{l}\text { Champions taught to } \\
\text { program 'tasks'. } \\
\text { Prioritising process } \\
\text { change around are } \\
\text { champions. } \\
\text { Expanding MI } \\
\text { university wide }\end{array}$ \\
\hline
\end{tabular}


During Phase I (system selection) there was a predominance of interactive strategising by the top management team. They consulted with the community: "I don't think we were given the choice of which system we wanted, but certainly we were involved with 'what sort of activities do you currently entertain in your own[Faculty/School]'" (Information Systems Group member 1, working in a Faculty/School at the time). This interactive and inclusive tone set the scene for the recruitment of individuals from the whole organisational community during subsequent phases. The broad goal of a system to support the whole organisational community was set: "part of the plan was to extend the range of administration undertaken by the central system. So that meant getting rid of the [Faculty/School] systems" (Academic Registrar and Director of Planning).

Phase II stage 1 (central system implementation) was predominantly procedural. It was driven by a formal project management methodology, with formal governance structures. Built into these structures were principles of recruiting representatives from the broader community. The Enterprise System Custodian Team was formed and became the project team for the implementation. It explicitly included two Faculty/School members as "champions...regarded very much as [Faculty/School] people [whose] advice was accepted by academics". (Academic Registrar and Director Planning).

The Steering Committee was also designed to encourage broad recruitment within the community. Academics as well as administrators were involved in this committee, and it was chaired by an academic. The goal for this immediate phase was the replacement of admissions functionality, although this was still set within the context of the broader goal of a system to support the whole University.

Guided support was provided by Enterprise System Custodians in terms of migrating data and mapping processes. This support was limited by tight timelines and scarce resourcing - with the exception of the project manager, people working on the project also continued with their operational roles. This did not have a noticeable impact on processes, as little change was required: "the procedures were already there, to a certain extent, so it was just matching the new system to those existing procedures" (Information Systems Group member 1). However, there was limited time to build knowledge and understanding of data: "due to lack of time, you'd copy over exactly what was in the old system to the new one, rather than rethinking it" (Information Systems Group member 2). In subsequent phases, some of these quick decisions regarding data were shown to have reduced potential fluidity.

By Phase II stage 2 (Faculty/School system implementation) the formal strategising activities of Phase II stage 1 formed a bedrock for a more interactive stage. The project management team remained in place, as did the Steering Committee. The top management team introduced principles of persuasion to drive recruitment: "You have to be able to take academics on in debate" (Academic Registrar and Director Planning). This persuasion involved "lots of visits, lots of meetings." (Information Systems Group Member 1). The top management team expected goal orientation to occur from demonstrated system benefits: "The view was that you should try and get it working for somebody and then everyone else will love it and join and come on board" (Information System Group member 1). Once the Enterprise System Custodians had recruited people into using the system, high levels of interaction helped to ensure that there was understanding and agreement on processes: "Once they did agree to do it, there was lots of working with them as well" (Information 
Systems Group member 1). Rigidities from imposing the system on unwilling, unprepared individuals were thus avoided. By the end of Phase II, the system was being used for central administration, for most processes in one Faculty/School, and for undergraduate processes in another. There was one Faculty/School who “Just hadn't any faith in it at all. Because they weren't forced to use it, they wouldn't come on board" (Information Systems Group member 1).

Phase III (consolidation) could be characterised by extending systems use into more Faculty/School operations. Once again, this phase was largely interactive. By now, the Enterprise System Custodians were operating as a largely self-managing team - the project manager had left the organisation. Governance mechanisms evolved to support prioritisation of the team's workloads, and were accompanied by high levels of informal interaction with the Top Management Team.

The most important method of recruitment used by the Enterprise Systems custodians was the identification of champions: "We have found that projects that have worked have been because there has been a champion there" (Information Systems Group member 1). The top management team supported these champions, largely via informal means in this phase: "We rely on having a champion to drive things forward" (Chair, Student Systems Steering Group). Once these champions have identified benefits from using the system, they are then able to demonstrate the benefits to colleagues: "I think when you've been sat down to do it from a paper manual perspective, then any kind of technological advantage is a benefit. We've sat here until 10 o'clock putting results in envelopes. You know, some of it is pretty soul destroying" (Post-Graduate examinations manager).

The Enterprise System custodians oriented the community towards the goal of using the system largely by demonstrating the effects of system use and mis-use in specific instances: for example, one Faculty/School found that there were no invigilators scheduled for their examinations, and it was demonstrated to them that this was because they had not updated the system with correct examination data. The top management team provided reinforcement of the messages regarding correct system use in interactions with the community.

Guided support by the Enterprise System custodians took several forms, including the mapping of processes, the transfer of data, and documentation. Increased fluidity of use occurred partly from improving the quality and access of data. Problems with data definitions introduced in the hurried data migration of Phase II were alleviated by means of a data review. Increased access to data was given by means of a management information suite based on Business Objects reports. During this phase, however, these reports were specific to individual Faculties/Schools and hard to adapt as requirements changed.

The main way that increased fluidity was established was by working with "champions" within the organisational community to ensure that the system supported their needs and that they used it knowledgeably. Interaction between the Enterprise System custodians and the organisational community remained high during Phase III and has continued to be so during Phase IV (current use). One member of the Enterprise Custodian team, for example, spends between $30 \%$ and $50 \%$ of her time in the Faculties/Schools. This is supported by the top management team.

Phase IV has been marked by increasingly proactive involvement by the Top Management Team. The interactive approach of previous phases is embedded in several procedural initiatives - a move to integrative strategising. Two major process reviews have significantly facilitated the potential 
recruitment of members of the organisational community. Each involved a two-day retreat: "complete end-to-end process reviews, with a view to streamlining activity and making it as efficient as possible" (Academic Registrar and Director of Planning). Enterprise System custodians identified some champions to include in the reviews, and identified new champions as a result of the reviews. They have then worked with these champions to embed process change using the system.

The top management team has also formalised the position of some "champions": people identified as such, for example, have been moved into a central team to manage industrial recruitment. New "champion" roles have been created: for example, each of the four Faculties/Schools will have a position with direct responsibility for data, which reports centrally to ensure an integrated approach.

Top management initiatives have provided significant goal orientation. The importance of one, integrated approach to processes and data has been promoted by the widely-used slogan "University 1 First". A cultural change programme has reinforced this approach. It was in two parts: a six month programme for two hundred middle managers, academics and support staff, and a similar one for senior staff. In addition top managers now sometimes mandate system use: "The mandatory side is, particularly really in the last four years. Registry have said, this is the only place we're really going to take information from to do our returns" (Information Systems Group member 2).

The portal is now a key means of guided support. It allows processes to be embedded in scripts, known as 'tasks'. It also both facilitates and necessitates improvements in the quality of data: on the one hand, data validation can be built into it, and on the other hand, data can only be displayed to students and staff if it is complete and correct, and its data file names are intelligible. Guided support is also provided by ongoing high levels of interaction with the community. There has also been further development of formal documentation and training sessions.

The Enterprise System custodians are aware of a potential draw-back to the portal: once 'tasks' are embedded this could introduce a new area of system rigidity. To avoid this, they are only automating processes where they have identified champions willing to retain responsibility for them. They then train these champions to program portal 'tasks' themselves, hence retaining the fluidity of the process. The top management team plays a significant role in supporting this method of prioritising processes.

Fluidity has also been increased by the consolidation and integration of management information. This has been done as part of the conversion of the management reporting software, Business Objects, to a web-based environment.: "Now we know that the reports that are there a) can be run for any [School/Faculty] in the University and b) we have reviewed them and they are still useful (Information Systems team member 1).

The Top Management Team and Enterprise System custodians continue to focus considerable effort on ensuring knowledgeable Enterprise System use. They expect this effort to continue, for four reasons. Firstly, many academics are not good at using the system and understanding processes: academics "do tend to mess up a lot of quite basic admin processes" (Administrative Head, Languages and Social Sciences). Secondly, some academics and administrators may not be interested enough to spare the time. It requires "emphasis on training colleagues who might not naturally be very interested in this kind of thing, on using these systems" (project manager, careers service). "We can see the benefits of spending quite a bit of time getting used to [the system], 
getting into [the system], getting to know what the functionality is, what they can get out of [the system]. But I don't think some people are prepared to give up the time to get the most out of it" (Information Systems team member 1).

Thirdly, it is not always clear who needs support: "it's such a devolved environment that, even if one person did [use the system correctly] it would only be for their small chunk of one [Faculty/School] that they would do it...trying to include all of those people can be very difficult because you're never really sure how many people you could include..they're not aware. 'If I don't put this piece of data into this field - who cares?' Whereas it does matter because it means the next process, that you're not responsible for, doesn't work" (Information Systems group member 2)

Fourthly, there are some areas where the system does not support University requirements very well. "Our systems are not 100 per cent successful ..for non-standard programmes" (Administrative Head, Life and Health Sciences). It is sometimes also hard to use; it is like "a blooming great mansion with lots of little cupboards and cubby holes, and knowing where particular data is stored is quite hard" (Chair, Student Systems Steering Group).

As a consequence, in order to ensure the continued, fluid use of the system, Enterprise System custodians cannot depend entirely on supporting and educating champions within the organisational community. There is ongoing need for Enterprise System custodians to correct system errors introduced by members of that community. 


\section{Results - University 2}

University 2 started the process for selecting a new system in February 2004, and the phasing of activities is described below. During these phases there has been significant restructuring. A new Vice Chancellor arrived in 2005. The restructure reduced the number of Faculties/Schools from eight to four, albeit still with considerable autonomy. Three Deputy Vice Chancellors, a Registrar, and Directors of Finance, Corporate Services and Human Resources were appointed, and the Director had been appointed just before the Vice Chancellor arrived, and has remained in place throughout the implementation.

\section{Phases of implementation and use}

The implementation can be characterised by Phase I, selection of system; Phase II, system implementation; Phase III, review, and Phase IV, current use.

Before Phase I, a central system produced statistical returns to Government, processed admissions and retained student records. The custodian was the Registrar. Faculties/Schools ran their own systems with manual uploads to the central one. The motivation for replacing the system was largely due to some technical problems with the system in place. The new system was selected, and Phase I was completed in 2004.

Phase II had two stages. Stage 1 replaced central functionality. Stage 2 involved the replacement of Faculty/School functionality. During Stage 2, use of the system was mandated and extended across the University. There was also a parallel project to build a management information suite based on data in the new system. Phase II was formally closed in December 2008.

Phase III consisted of a moratorium on further development, a review of the previous phase, and recommendations for using the system in the future. It was completed in 2010. Phase IV, 2011 onwards, has seen several activities to ensure that the system is embedded, and to link system activities to an extensive management information suite. It has also seen some initial developments of a portal, in the area of student enrolments.

\section{Strategies and the Enterprise System}

Research, Enterprise, Students and Financial Sustainability have been identified as the main formal strategies (University Strategy and Four Year Plan 2011). Interviews have indicated that the new Vice Chancellor has driven the focus on research and teaching for academics. Before his arrival "as long as academics were busy, it was OK" (Director IT). Now, measurable research outcomes are regarded as a core activity for them: "The single most important step is to improve the quality of our published academic work, as judged by the number of citations it receives" (University Strategy and Four Year Plan 2011).

Academics are also expected to work to "provide ...students with the highest quality learning experience that combines academic rigour, personal development and employability" (University Strategy and Four Year Plan 2011). The emphasis on the learning experience as a core strategy is placed in the context of "a wider objective to increase ..student services.. including Library, IT and on-line self service academic administration." (University Strategy and Four Year Plan 2011). Hence student administrative experience is seen as important, but not directly related to the core strategy of student learning experience. 
Enterprise describes the translation of outcomes from research portfolios into tangible benefits for society. Financial sustainability describes an aim to achieve specific net surpluses, by improving administrative effectiveness and hence reducing costs, and by growing in student numbers and hence increasing revenue. In addition to the stated strategies, interviewees stressed the importance of Government compliance via accurate, detailed returns, simply as a means of survival. If inaccurate statistics are reported then: "there could potentially be a clawback of funding and adjustment to our funding levels. So they're very significant." (Director Planning). A recent clawback of $£ 36.5$ million and reduction of further funding of $£ 15$ million at another university (Melville 2009) has "sent waves of concern across nearly every institution in the land." (Director Planning). Table A.5 shows the direct and indirect relationships between strategies and the Enterprise Systems at each phase.

Table A. 5: Relationship between phased Enterprise System activities and strategies, University 2

\begin{tabular}{|c|c|c|c|c|c|c|c|}
\hline \multirow{3}{*}{\multicolumn{2}{|c|}{ Enterprise System activities }} & \multicolumn{6}{|c|}{ Overall strategies } \\
\hline & & \multicolumn{2}{|c|}{ Core } & \multicolumn{4}{|c|}{ Non-core } \\
\hline & & $\begin{array}{l}\text { Res- } \\
\text { earch }\end{array}$ & $\begin{array}{l}\text { Student } \\
\text { learning } \\
\text { exp'ce }\end{array}$ & $\begin{array}{l}\text { Student } \\
\text { admin } \\
\text { exp'ce }\end{array}$ & $\begin{array}{l}\text { Gov't } \\
\text { Comp- } \\
\text { liance }\end{array}$ & Growth & $\begin{array}{l}\text { Admin } \\
\text { Effect- } \\
\text { iveness }\end{array}$ \\
\hline & \multicolumn{7}{|c|}{ Phase I - system selection 2004} \\
\hline \multirow[t]{2}{*}{ Data } & Central system for gov't returns & & & & $x x x$ & & \\
\hline & \multicolumn{7}{|c|}{ Phase II Stage 1 - central system implementation $2004-2005$} \\
\hline \multirow[t]{2}{*}{ Data } & Central system for gov't returns & & & & $x x x$ & & \\
\hline & \multicolumn{7}{|c|}{ Phase II Stage 2 - faculty/school system implementation 2008} \\
\hline Data & Central system for gov't returns & & & & $x x x$ & & \\
\hline $\begin{array}{l}\text { Proc- } \\
\text { ess }\end{array}$ & Faculty/school coordination & & & & $x x x$ & & $x x x$ \\
\hline \multirow[t]{2}{*}{$\mathrm{Ml}$} & University-wide mgt info & $\mathrm{x}$ & $\mathrm{x}$ & & & & $x$ \\
\hline & \multicolumn{7}{|c|}{ Phase III review 2009-2010 } \\
\hline Data & Central system for gov't returns & & & & $x x x$ & & \\
\hline $\begin{array}{l}\text { Proc- } \\
\text { ess }\end{array}$ & Faculty/school coordination & & & & & & $x x x$ \\
\hline \multirow[t]{2}{*}{ MI } & University-wide mgt info & $\mathrm{x}$ & $\mathrm{x}$ & & & $\mathrm{x}$ & $\mathrm{x}$ \\
\hline & \multicolumn{7}{|c|}{ Phase IV current use 2011 onwards } \\
\hline \multirow[t]{2}{*}{ Data } & Central system for gov't returns & & & & $x x x$ & & \\
\hline & $\begin{array}{l}\text { Integrated data available to } \\
\text { students }\end{array}$ & & & $x x x$ & & & $x x x$ \\
\hline $\begin{array}{l}\text { Proc- } \\
\text { ess }\end{array}$ & Self-service portal for students & $x$ & $\mathrm{x}$ & $x x x$ & & & $x x x$ \\
\hline $\mathrm{Ml}$ & University-wide mgt info & $x$ & $\mathrm{x}$ & & $\mathrm{xxx}$ & $\mathrm{xxx}$ & \\
\hline Key & $\begin{array}{ll}x x x: & \text { direct relationship } \\
x: & \text { indirect relationship }\end{array}$ & & & & & & \\
\hline
\end{tabular}

During Phase I and Phase II stage 1 the system provided returns to government, but was not otherwise involved in any strategic support. That changed in Phase II stage 2 once the Faculties/Schools became involved in the implementation. This involvement led to improved compliance at the Faculty/School level, as university-wide regulations became more visible and forced changes to processes. 
The management information suite built using data from the system during Phase II incorporates a cascading series of Key Performance Indicators. These are available to Faculty/School heads for use in an appraisal system which forms part of the management of academic staff. "[We have] four year targets for KPIs. We've got score cards that you can follow through from one of these high level University objectives...through to a Faculty/School, a department, and then the individual being appraised, and the head of department's got to enable them to set objectives that are aligned." (Director Planning). This appraisal system has the potential to affect research and the student learning experience indirectly.

The student administrative experience was largely unaffected in the first three phases, and indeed there was one situation where it may have deteriorated. A previous system developed in the Faculty/School of Business, Economics and Law was decommissioned as part of the implementation. That system included the functionality for students to upload their assignments electronically and receive their marks back via a portal. It also contained workflow and audit trails to manage the marking.

For Phase IV, from 2011 onwards there has been explicit differentiation of the type of IT support provided for core and non-core goals respectively: "for learning and teaching..in terms of IT support, we want to be a thing of excellence. We want to be up with the leading institutions of the field. Whereas for corporate applications, ..we don't regard that as an area where we should excel. We should just be cheap and reliable" (Director IT, referring to a diagram of the structure of IT strategy).

Administrative effectiveness and the student administrative experience have both been improved by the first portal developments. Self-service student re-enrolment has been introduced, and plans were made to follow this with student selection of curriculum and display of marks to students.

Growth is expected to be helped by the detailed provision of statistics to student league tables . A leap in the university's league table position is "very good news for us" (Director Planning). This is in the context of the Browne Review (2010) which allows universities to charge significantly higher fees to students, and has also recommended more detailed information to such students, resulting in the Government website, Key Information for Students (HEFCE 2013a). This information is reinforced by other web sites, run mainly by newspapers - see for example (Guardian 2013).

\section{Top Management Team and Enterprise System Custodian Activities}

Table A. 6 summarises the activities of the top managers and Enterprise System custodians at University 2. 
Table A.6 : Patterns of strategising and scaffolding at University 2

\begin{tabular}{|c|c|c|c|c|}
\hline Team & Recruitment & Goal orientation & Guided support & Increasing fluidity \\
\hline \multicolumn{5}{|c|}{ Phase I- pre-active } \\
\hline TMT & $\begin{array}{l}\text { Deliberate limitation } \\
\text { of decision-making } \\
\text { to central team. } \\
\text { Governance } \\
\text { included broader } \\
\text { representation. }\end{array}$ & $\begin{array}{l}\text { System to support } \\
\text { central processing } \\
\text { only. Importance of } \\
\text { high quality data. }\end{array}$ & & \\
\hline ESC & & & & \\
\hline \multicolumn{5}{|c|}{ Phase II stage 1 - pre-active } \\
\hline TMT & $\begin{array}{l}\text { Central ESC team. } \\
\text { Governance } \\
\text { structures continued }\end{array}$ & $\begin{array}{l}\text { Continued focus on } \\
\text { changing central } \\
\text { functionality, and } \\
\text { importance of data } \\
\text { quality. }\end{array}$ & & \\
\hline ESC & $\begin{array}{l}\text { Admissions team } \\
\text { recruited into using } \\
\text { new system }\end{array}$ & $\begin{array}{l}\text { Admissions support } \\
\text { on new system }\end{array}$ & $\begin{array}{l}\text { Data conversion, } \\
\text { process change }\end{array}$ & \\
\hline \multicolumn{5}{|c|}{ Phase II stage 2 - procedural } \\
\hline TMT & $\begin{array}{l}\text { Formalised extensive } \\
\text { recruitment, via } \\
\text { governance } \\
\text { structures and } \\
\text { enforced use. }\end{array}$ & $\begin{array}{l}\text { Mandating activity } \\
\text { to use system } \\
\text { University-wide }\end{array}$ & $\begin{array}{l}\text { Resourcing formal } \\
\text { project activities }\end{array}$ & $\begin{array}{l}\text { Granting stay of } \\
\text { execution }\end{array}$ \\
\hline ESC & $\begin{array}{l}\text { Difficulties in } \\
\text { motivating recruited } \\
\text { individuals. } \\
\text { Identification of } \\
\text { system expert users }\end{array}$ & $\begin{array}{l}\text { Executing mandated } \\
\text { activity }\end{array}$ & $\begin{array}{l}\text { Working with } \\
\text { Faculties/Schools. } \\
\text { Data migration. } \\
\text { Regulations } \\
\text { embedded in } \\
\text { system. Formal } \\
\text { training }\end{array}$ & $\begin{array}{l}\text { Observation of } \\
\text { rigidities due to lack } \\
\text { of process and data } \\
\text { awareness . } \\
\text { Requesting stay of } \\
\text { execution }\end{array}$ \\
\hline \multicolumn{5}{|c|}{ Phase III procedural (review) } \\
\hline TMT & $\begin{array}{l}\text { Interviewing and } \\
\text { surveying staff } \\
\text { broadly }\end{array}$ & $\begin{array}{l}\text { Goals arose out of } \\
\text { review findings }\end{array}$ & $\begin{array}{l}\text { Project governance } \\
\text { framework, process } \\
\text { orientation. }\end{array}$ & $\begin{array}{l}\text { No system } \\
\text { development } \\
\text { allowed }\end{array}$ \\
\hline ESC & $\begin{array}{l}\text { Identification of } \\
\text { system coordinators }\end{array}$ & $\begin{array}{l}\text { Goal to maintain } \\
\text { system use }\end{array}$ & $\begin{array}{l}\text { Support required for } \\
\text { ongoing system use }\end{array}$ & \\
\hline \multicolumn{5}{|c|}{ Phase IV integrative } \\
\hline TMT & $\begin{array}{l}\text { Interactive } \\
\text { discussions. } \\
\text { Recruitment of } \\
\text { further system } \\
\text { experts via small } \\
\text { organisational } \\
\text { restructures. }\end{array}$ & $\begin{array}{l}\text { Process based } \\
\text { approach } \\
\text { Vision sessions, KPIs }\end{array}$ & $\begin{array}{l}\text { Project and } \\
\text { governance } \\
\text { framework, process } \\
\text { orientation. }\end{array}$ & $\begin{array}{l}\text { Support for process } \\
\text { change }\end{array}$ \\
\hline ESC & $\begin{array}{l}\text { Increasing levels of } \\
\text { consultation, and } \\
\text { identification of } \\
\text { system experts. }\end{array}$ & Benefits of system & $\begin{array}{l}\text { Processes, data, } \\
\text { training, ITIL }\end{array}$ & $\begin{array}{l}\text { Data definition } \\
\text { review, } \\
\text { Knowledgeable } \\
\text { process change. }\end{array}$ \\
\hline
\end{tabular}


During Phase I the strategising of the top management team could be characterised as pre-active: there was deliberate limitation of scope regarding both the involvement of the organisational community in the choice of the new system, and the proposed influence of the new system. The Registrar was the custodian for the old central system which: "was renowned for the quality of its data...down to microscopic levels...administratively very robust" (Student Systems Manager). He instituted the selection project with a view to replacing the central student record system and for "no other reason" (Director IT). As a consequence, changes to Faculty/School processes were not considered, because the Registrar recognised that this would require skills changes, and would involve "battles" (Director IT). This was in the context of a University where the top management team was drawn directly from the academic community on a rotational basis. The Vice Chancellor was "very focussed on research, and also focussed on the University's reputation outside. So the [Faculties/Schools] were left very much to their own devices. There wasn't very much managerial steer, if you like" (Academic Registrar). It should be noted that, despite this limited scope, there was a Project Board for system selection, including staff from the Registry, IT services and Faculties/Schools (Post Implementation Review).

These limitations to scope and involvement of the organisational community continued during the first stage of Phase II (the implementation of centralised functionality), which was hence also preactive. This was not a problem: indeed, this stage was regarded as "a quiet success" (Director IT). However, the second stage was affected both by changes in personnel, and a radical change in scope. Faculty/School process support was now to be included in stage 2 of the rollout: the longstanding Registrar retired. "The new Registrar...came on board with a different brief and a different management style. It became apparent that, with the changes in personnel both at the Centre and in the Faculties/Schools, there was a need to revisit the whole "what are our processes"' (Director IT). Availability of resources was also impacted by the restructure: "in the summer of 2007 ...all the people involved in student administration were going through the whole process of their jobs being changed, advertising for jobs, etc." (Director IT). It was felt that plans for Phase II stage 2 did not allow for this very large amount of parallel activity.

The top management team used mainly procedural means to implement this radical change of scope and organisational commitment. System use was mandated. A project team was formed including both IT and Registry staff. Governance structures, including a Project Board, were put in place in an attempt to engage the broader community. These procedures met with mixed success. The project team worked successfully together, and the fortnightly planning group involving IT and the Registry was "very lively" (Student Systems Project Manager). The same could not be said of the broader Governance structures: "whether there was representation in terms of attendance [was questionable]...I think of the same faces, the Registry and IT people who were there" (Student Systems Project Manager). System experts were identified within Faculties/Schools, but the numbers involved made coordination of change difficult: "they established...expert users with various levels of access into the system.....we ended up with something like 70 experts ...when, in fact, it was only intended to be a dozen at most" (Academic Registrar).

Motivating staff was a problem. Faculty/School staff often saw the system as making more work for no clear advantage. The system: "requires more administrative involvement than previous systems.... it has been quite a big training and learning curve for the administrators. I think it's actually increased workload for the administrators" (Administrative Head, Business, Economics and 
Law). This was particularly a problem in situations where the new system had less functionality than the old, as in the case of the Faculty/School with the decommissioned student assessment portal mentioned previously. People had not yet learnt how to use the system to support their needs: "We didn't realise that once one process was done, that impacted on you not being able to do another process. They're the things we've discovered along the way" (Administrative Head, Business, Economics and Law).

Enterprise System custodians provided guided support by visiting Faculties/Schools. They also provided extensive training programmes, although these were not always well attended. "Some ...staff either didn't come to training, or they came to every training session but didn't take on board what they were being told" (Academic Registrar). "There was a lot of training and I think a bit of training overload. Until you actually went back and used the system and saw the processes through, it was difficult to always relate the training to what you were actually going to do in the office" (Administrative Head, Business, Economics and Law).

During this stage the Enterprise System custodians became concerned about rigidities being introduced into the system. A lack of discussion regarding processes resulted in heavy customisation in some instances. For example, multiple progression rules are now embedded in the system, reflecting separate Faculty practices which have "added time, effort, complexity" (Student Systems Project Manager). There were some minor problems with data migration for the cohorts of students whose records were held on both the old and the new systems, although these were seen as temporary. Of more concern was a lack of understanding of the system, which led to wrong or incomplete data. The Enterprise System custodians: "had to unpick what staff in the [Faculties/Schools] thought they had done properly" (Academic Registrar).

Eventually, the Enterprise System custodians became concerned enough by the lack of engagement of the organisational community to request a stay of execution. They believed that, if the implementation continued without this engagement, the system might become rigid. Practices, such as the multiple progression rules, would become embedded in the system with no further potential for process change. Data quality would deteriorate without improved awareness of the importance of data to the organisation. The top management team granted this stay of execution, and the system eventually went live in 2008, for the whole University: "in the summer of 2009 we graduated over 2000 students. They all had a transcript. They all had a degree certificate. It came off the system." (Academic Registrar).

During Phase III, the top management team stopped all system development. They undertook a formal review. The review group included members of Faculty administration, academic staff, Registry and central management. They interviewed senior Faculty administrators, members of the Project Board, members of the Enterprise Systems custodian team, and Registry staff. They also surveyed the University community as a whole. Conclusions of the review were that a shared vision for and ownership of the system should be developed, and that student processes should be reviewed on a University-wide basis. All future work would involve formal project management structures and processes. Apart from being interviewed, the work of Enterprise Systems custodians during this phase was concerned with continuing to maintain system use. (Post implementation review (2010)) 
Phase IV can be characterised as exhibiting integrative strategising. The procedures introduced in earlier phases are now complemented by more interactive practices. Recruitment of the members of the organisational community includes more discussion: "in recent years there's been a lot of consultation and discussion within the [Faculties/Schools], so that we have input into those" (Administrative Head, Business Economics and Law).

The identification and use of systems experts has become more effective. This has happened by both procedural and interactive means. There have been mini-restructures: a new position has been created in each Faculty/School: "A Student Administration Coordinator...the person you would turn to when you weren't sure what to do...this person would be an expert" (Academic Registrar). The administrative heads of Faculties/Schools now report directly to the new Registrar, rather than to their Deans, which has made it easier for them to ensure that they can support integrated use of the system. These structural changes are seen as supporting process reviews: "I think there was an implicit belief before that if you do process reviews, you will come up with a rational organisational structure..whereas in reality I think it's more effective to [say] this group of people are now going to be responsible for the following things: what processes do we need to follow to deliver those tasks? [Otherwise] people put a lot of energy into defending the status quo" (Director IT).

Experts have also been identified interactively as part of "ongoing process review". (Administrative Head, Business, Economics and Law). Members of different Faculties/Schools identify areas of expertise: "there seem to be pockets...a particular pocket will be good at admissions [and another] will be good at, say, timetabling." (Administrative Head, Business, Economics and Law).

The Vice Chancellor has become personally involved in goal orientation, by relating non-core and core strategies. He has introduced: "briefing sessions [with 20 people at a time]. He's open, transparent about where we need to be. Particularly in this climate of change to student funding. How we are responding to it. How we're doing financially. How we are against our peers" (Student Systems Program Manager). Goal orientation is also occurring as people see the benefits of using the system: "we do a lot more reporting than we used to...from that point of view...it is a very powerful tool in the data and information it holds" (Administrative Head, Business, Economics and Law). "Producing the board reports for the examination boards...seems to work quite well actually...So that would be one thing that's definitely improved" (Student Systems Expert, Business, Economics and Law). Goal orientation also occurs as people see the disbenefits of using the system incorrectly. For example, the Key Performance Indicators used in personal appraisals use system data, so wrong data can have immediate personal impact. The first portal initiatives to support online student re-enrolment, and to enhance class lists and student details, have also been seen as beneficial.

Guided support in the form of process reviews, training and documentation is supported by the new governance framework. It is also supported by specific standards: for example a training programme is being rolled out using the Information Technology Infrastructure Library (ITIL). Starting with Registry staff, it will gradually be rolled out across the University, to ensure the community speaks a common language.

Fluidity is being encouraged by these new approaches. People now understand the need for process change, and the costs of not understanding processes. Conversations regarding system support are: "led by two things. What processes do we need, and what systems out of the box can deliver those? 
I think there's a lot less appetite for heavily customised packages, because people can see the long term costs of doing that" (Student Systems Program Manager). Fluidity is also being increased by data quality initiatives. "We don't have consistent data definitions... we are making a list of issues regarding data definitions and how they are structured". (Director IT).

Scaffolding activities, then, continue to improve Enterprise System practices among the organisational community. However, the challenge of involving an organisational community which may lack the motivation, skills and time to use the system is recognised: "My sympathies are all with my academic colleagues, to be honest, because I think with the pressures of both scoring research excellence and to respond to critical review from things like the National Student Survey plus at the same time, to be encouraged to support colleagues to use more self-service options - I think they must at times feel like it's quite an impossible task. It's almost contradictory in expectations, isn't it, to be an excellent individual researcher and to be a good corporate citizen?" (Director IT). 